\title{
Herod and Mariamne
}

A Tragedy in Five Acts by

Friedrich Hebbel

Translated by

Paul H. Curts 
Herod and Mariamne 


\section{IIIIUNC}

From 1949 to 2004, UNC Press and the UNC Department of Germanic \& Slavic Languages and Literatures published the UNC Studies in the Germanic Languages and Literatures series. Monographs, anthologies, and critical editions in the series covered an array of topics including medieval and modern literature, theater, linguistics, philology, onomastics, and the history of ideas. Through the generous support of the National Endowment for the Humanities and the Andrew W. Mellon Foundation, books in the series have been reissued in new paperback and open access digital editions. For a complete list of books visit www.uncpress.org. 


\section{Herod and Mariamne}

\section{A Tragedy in Five Acts by Friedrich Hebbel}

TRANSLATED BY PAUL H. CURTS

UNC Studies in the Germanic Languages and Literatures Number 3 
Copyright (C) 1950

This work is licensed under a Creative Commons CC BY-NC-ND license. To view a copy of the license, visit http://creativecommons. org/licenses.

Suggested citation: Hebbel, Friedrich. Herod and Mariamne: A Tragedy in Five Acts by Friedrich Hebbel. Translated by Paul H. Curts. Chapel Hill: University of North Carolina Press, 1950. DOI: https://doi. org/10.5149/9781469657349_Hebbel

Library of Congress Cataloging-in-Publication Data Names: Curts, Paul H.

Title: Herod and Mariamne : A tragedy in five acts by Friedrich Hebbel / by Paul H. Curts.

Other titles: University of North Carolina Studies in the Germanic Languages and Literatures; no. 3.

Description: Chapel Hill : University of North Carolina Press, [1950] Series: University of North Carolina Studies in the Germanic Languages and Literatures.

Identifiers: LCCN 51000895 | ISBN 978-1-4696-5733-2 (pbk: alk. paper) | ISBN 978-1-4696-5734-9 (ebook)

Subjects: Herod I, King of Judea, 73 B.C.-4 B.C. - Drama. | Mariamne, consort of Herod I, King of Judea, approximately 57 B.C.-approximately 29 B.C. - Drama. Classification: LCC PD25.N6 NO. 3 


\section{INTRODUCTORY NOTE}

The better works of foreign literature should be available to the reading public in English translation. The more nearly they are reproduced in the form and spirit of the original, the more such works enrich our own great store. It is with this in mind that I have translated Hebbel's masterpiece Herod and Mariamne, probably the greatest German drama of the nineteenth century.

Christian Friedrich Hebbel was born in the village of Wesselburen in Ditmarsch, Holstein, on March 18, 1813. He died in Vienna on December 13,1863 . The gloomy bleakness of northern Germany, the poverty of his home, the strict and sometimes violent discipline of his father had a permanent effect on his character. His was a serious, sensitive, imaginative nature, strong-willed even to the point of obstinacy.

Convinced early in life that he was to make his mark as a writer and a poet, he left his narrow provincial home and devoted himself to the achievement of his literary aims with an unswerving fixity of purposein spite of hunger, hardship, and disappointment. He endowed the characters of his dramas with the same fixity of purpose which he himself possessed, with a rigid, unswerving, relentless adherence to a point of view.

Hebbel was persuaded that the most tragic situations of life arise, not necessarily from any moral guilt, but rather from conflict between the individual will and its environment, and that this conflict is most significant when a vital change is taking place in the existing state of the world. His most important dramas are located at such critical times in history. In its early stages the conflict between the old established order and the representative of the new order is tragic for the new, but suggests hope for a brighter future. Such a conflict is the core around which most of Hebbel's tragedies are built. The individual undergoes a process of inner change and must inevitably suffer in a conflict with the whole, but the new cause is advanced, although it be but slightly. The Hegelian philosophy: thesis, antithesis, synthesis, is presented here in dramatic form.

The tragic story of Herod and Mariamne has appealed to many dramatists. For all of them the only historical source is Flavius Josephus in The Jewish War (75 A.D.) and The Antiquities of the Jews (93 A.D.). Hebbel is the first of these dramatists for whom the historical events are merely the background and for whom the real drama lies in the inner psychological development of the characters.

Herod was the King of Palestine from 37 B.C. to 4 A.D. The action takes place in the period just prior to the beginnings of Christianity. Though really an enlightened monarch for his day and even a reformer, Febbel's Herod knows only the traditional methods of procedure, he still represents the old tyrannical order and represents it more completely 
as the play develops. From our point of view the change in him is retrogressive. Although Mariamne can be just as ruthless as Herod toward those beneath her, there is in her the first suggestion of the new order. Conscious of her own worth as an individual, she expects trust and confidence from Herod. When she does not receive them, life loses all value for her, and she deliberately brings on her own death at the hands of Herod. Less rigid and unyielding characters might have reached a compromise. With characters such as Hebbel depicts, tragedy is unavoidable. Herod is not only in love with Mariamne, he is an Idumean and a king, as Mariamne is a Maccabean and the daughter of Alexandra. Try as he will, Herod cannot forget the king for love of Mariamne, nor can she forget the Maccabean for love of him (lines $1005 \mathrm{ff}$.). Tradition and heredity are too strong for them. The necessity for tragedy lies within the characters themselves, not outside of them in a superhuman power. This is the modern fate tragedy.

A forerunner of Ibsen and naturalism, Hebbel was too early for his contemporaries. The performance of Herod and Mariamne in Vienna in 1849 and that in Berlin in 1874 could not but fail miserably, for neither the public nor even the directors and the actors understood either Herod or Mariamne and the nature of their tragic inner struggle. With the turn of the twentieth century appreciation began to dawn and since then this drama has appeared with fair regularity on the important German stages, reaching a high of 158 performances in one season. Herod and Mariamne will never enjoy wide popularity with the masses. To appreciate Hebbel the audience must think as well as feel, and that is not the mood in which most people attend the theater.

Hebbel wrote his drama in unrhymed iambic pentameter. The form is that of the classic German drama. The language, however, is straightforward, realistic, contemporaneous. It is the common language of his day, not colloquial, but simple and dignified. To produce as neariy as possible the same effect in translation, I have used a dignified, straightforward, modern English, avoiding exalted diction on the one hand and otvious colloquialisms on the other. I have tried to express Hebbel's ideas as he might have expressed them, had English been his medium. Translation in this spirit is a difficult task in prose, doubly so when it must be metrical and at the same time faithfully render the meaning of the original. Even with the difficulties it is surprising how literal the translation can be.

The translator desires to express his appreciation to Professors T. Moody Campbell, John C. Blankenagel, Homer E. Woodbridge, Arthur R. Schultz, Richard Jente and Frederic E. Coenen for their constructive criticism and many helpful suggestions, and to the Research Committee of Wesleyan University for the financial grant, which helped make publication possible.

Middletown, Connecticut

Paul H. Curts. 
HEROD AND MARIAMNE 


\section{CHARACTERS}

hing Herod

MARIAMNE, his wife

ALEXANDRA, her mother

SALOME, sister of the king

Sozmus, Governor of Galilee

JOSEPH, husband of Salome, Viceroy in absence of the King

SAMEAS, a Pharisce

Titus, a Roman captain

JOAB, a messenger

JUDAS, a Judean captain

ARTAXerXes, a servant

Moses )

JFHU $\}$ servants, as well as other servants

Silo, a citizen

ZERUBBABEL and

PHILO, his son $\}$ Galileans

A Roman Messenger

AARON, and five other judges

T'HRe Kings of THe ORIENT, later called Saints by the Christian Church

Flace: Jerusalem

Time: about the birth of Christ 


\section{ACT I}

Castle Zion. Large audience room. Joab. Sameas. Zerubbabel and his son. Titus. Judas, and many others. Herod enters.

\section{SCENE 1}

JOAB (advances toward the King).

I have returned!

HEROD. Save your report till later!

The most important business first!

JOAB (stepping back, aside). Important!

I thought the most important was to learn

Whether or not our head still sits secure!

HEROD (summons Judas).

Tell me about the fire!

JUDAS. About the fire?

So you already know the news I bring?

HEROD. That it broke out at midnight, yes. I was

The first who noticed it and called the watch.

If I am not mistaken, I woke you!

JudAs. The fire is out. (aside) So what they say is true,

That in disguise he prowls the streets

While others sleep! We must be on our guard

Lest careless words might sometime reach his ear.

HEROD. When everything stood wrapped in flame I saw

A woman through the window of the house

Who seemed benumbed. Was this young woman saved?

JuDAs. She did not want to be!

JEROD. Not want to?

JUDAS. $\quad$ No!

She fought against them when they tried to take

Her out by force, she struck at them with hands

And feet, she clung with desperation to the bed

On which she sat, and cried that she had been

About to kill herself with her own hands

And now a kindly fate brought death to her.

FisRod. She must have been demented!

JUDAS. Possibly

Her mind had been upset by pain and grief!

Her husband had just died a while before, His body lay still warm upon the bed.

HERod (aside). That I will surely tell to Mariamne

And watch her while I tell her! (aloud) Probably

This woman had no child! But if she had,

I will take care of it! She shall herself

Be buried richly and with royal splendor,

She was, it may well be, the queen of women! 
Sameas (steps forward). Be buried! That is not permissible!

At least not here, not in Jerusalem!

For it is written in-

HEROD.

Do I not know you?

SAMEAS. You had occasion once to know me, yes:

I served the Sanhedrin as tongue that time

When it sat mute before you.

HEROD.

Sameas,

I hope you know me too! You hated Herod

When he was young. You would have liked so much

To make his head a present to the hangman.

The man and king has now forgotten that,

For you still have your own head on your shoulders.

SAmEAS. If for the reason that you let me keep it

I must not use it now, then take it from me;

That would be worse by far than losing it.

HeroD. Why did you come? Till now I never saw you

Within these walls.

SAMEAS. But that is just the reason

You see me now. Perhaps you thought I stood

In awe of you. I have no fear of you,

Not even now when many men nave learned

To fear, who did not use to be afraid,

Before Aristobulus met his death.

And since the opportunity has come

To prove to you that I am thankful, I take

Advantage of it and give solemn warning

Against an act which God the Lord condemns.

Accursed are this woman's bones, for she

Resisted rescue as a Gentile might,

And that is quite as if she killed herself,

And since-

HiERod. Some other time! (to Zerubbabel) From Galilee!

Zerubbabel, who was-I bid you welcome!

The blame is yours, I did not see you sooner!

ZERUBBABEL. It is an honor, King, that you still know me!

(points to his mouth)

Of course these two great tusks of teeth I have,

That make me like the cousin to a boar-

HEROD. I would forget my own face sooner far

Than that of one who served me faithfully!

When we were hunting robbers to their lair

You tracked them best. What do you bring me now?

ZERUBBABEL (beckons his son).

In fact not much! Just Philo here, my son!

You have a need for soldiers, I do not,

And this boy is a Roman, whom, it happened,

A Hebrew woman brought into the world. 
FHEROD. What comes to me from Galilee is good!

You may expect a summons soon!

(Zerubbabel and his ston step back)

Titus (steps forward).

A fraud

Which I discovered forces me-

HEROD.

Trius. The dumb speak!

HEROD.

Titus.

Please be clear!

Disclose it!

Who stood on watch before your bedroom door

Last night with one of my centurions-

Herod (aside). Whom Alexandra recommended to me,

My mother-in-law-I see!

Titus.

$\mathrm{He}$ is not dumb,

As everyone has always thought he was;

He spoke aloud last night in sleep, he cursed!

HEROD. In sleep?

TITUs. He fell asleep while standing watch,

And my centurion did not awake him;

He did not think he was responsible,

Because he is not in the cohort with him,

But yet he kept close watch, so as to catch him

If he should fall. For it was early still,

You were asleep, he did not want to rouse you.

Then suddenly, as he is watching him,

The dumb man starts to mumble, speaks your name,

And calls down fearful curses on your head.

HEROD. Can the centurion have been mistaken?

Tirus. He would have had to be asleep himself;

And that would be an omen worse by far

For the eternal city than the lightning

That struck the Capitoline wolf not long

Ago.

HEROD. I thank you! Now-(he dismisses all but Joab)

Yes, so things stand!

Rank treason in my house, and in the crowd

Of Pharisees defiance, bolder still

Because I can not punish them at all

Unless I make the fools appear as martyrs;

A little love among the Galileans,

No, mere attachment of a selfish sort,

Because I am the bogey with the sword

Who from the distance scares their rabble so;

And-this man Joab surely brings bad news,

He was too anxious to announce it to me.

For even he, although he is my servant,

Likes doing what will vex me, if he knows

That I must act as if I did not notice! 
(to Joab) What news have you from Alexandria? JoAB. I spoke with Antony. HEROD.

A strange beginning!

You spoke with Antony? I am accustomed

To have the messengers I send received;

You are the first who finds it necessary

Thus to assure me that he was successful.

JoAB. They made it hard for me. They put me off, Time after time!

HEROD (aside). He stands then with Octavius

On better terms than I had thought! (aloud) That proves

To me, you failed to choose the prcper hour.

JOAB. I chose each one among the twenty-four

Of which the day consists; no matter how

They urged, I did not leave the spot, not even

When Roman soldiers offered me a meal,

And then, since I refused it, jeered at me:

He eats no food save what the cat has tasted

And what the dog has torn to shreds! At last

I was successful-

HEROD.

For a wiser man

It would have been at onceJoAB.

And was received.

It was already night and first I thought

He had me summoned merely to continue

The sport the soldiers had in jeering at me,

For when I came inside I found a group

of drinkers there, reclining at their ease.

But he himself poured out a glass for me

And said to me: Drink this to my good health!

And when I courteously declined to drink it,

He said: If I set out to kill this man

I only need to bring him to my table

For eight full days and on it place before him

The tribute earth and sea have rendered me,

He would not eat but only sit and starve

And dying swear that he had had his fill.

HEROD. Yes, yes, they know us well. That must be changed.

What Moses ordered only to prevent

Their worshipping the Golden Calf again-

If he was not a fool-this people still

Observes as if it were an end itself,

And so is like the sick man who, when healed,

Continues still to take the remedy

As if he thought that medicine were food.

That must-Go on! JOAB.

However, I was soon

Convinced that I was wrong, for while he drank 
He carried out all business of the state,

He named the magistrates, and made arrangements

To sacrifice to Zeus, heard auguries,

And interviewed the messengers who came,

Not me alone. It was quite strange to see.

A slave stood there behind him, ears alert,

A stylus and a tablet in his hand,

Ridiculously serious, recording

What he had said in his half drunken state.

Next morning then, still feeling the effects,

He reads the tablet through, or so I heard,

And holds to all it says so faithfully

That he-they say he swore this recently-

Would choke himself to death with his own hands

If in his cups at night he gave away

The world o'er which he ruled, and had thereby

Renounced his rights to any place within it.

Whether he staggers then, as well as when

$\mathrm{He}$ goes to bed at night, I do not know;

That seems to me to be of no import.

HEROD. You win, Octavius! The only question:

If now or later. Well? JOAB.

When finally

My turn had come and I had given him

The letter which I had for him from you,

Instead of opening and reading it,

He tossed it to his clerk quite scornfully.

$\mathrm{He}$ had his servant bring a portrait; this

He bade me look at carefully and tell him

Whether I found the likeness good or not.

HEROD. It was the portrait ... ?

JOAB.

Of A.ristobulus,

The young high priest, who drowned so suddenly.

The picture had been sent to him long since

By Alexandra, by your mother-in-law,

Who keeps in touch with him, and yet he gazed

With greedy eyes as if 'twere new to him.

I stood confused and silent there. He said,

When he saw this: Perhaps the lamps are burning

Too dimly here! and reached then for your letter,

Set it ablaze and let it burn out slowly

Before the picture like a blank white sheet.

Herop. Bold! Even bold for him! But-he was drunk!

JOAB. I cried: What are you doing there? You have

Not even read it yet! And he replied:

I want to talk with Herod, that's the meaning!

A charge of murder has been brought against him!

And now he had me tell how this high priest 
Had come to die. And when I said to him

A fainting spell had seized him in his bath,

He interrupted: Seized! Yes, yes, the word

Is chosen well; the fainting spell had hands!

And so I learned-forgive me if I say it!-

That they did not believe in Rome the youth

Had drowned, but rather they were quite convinced

That your own officers, at your command,

Had strangled him while bathing in the river.

HEROD. Thanks, Alexandra, thanks!

JOAB.

He motioned me

To go and so I went. But then he called

Me back and said: As yet you have not answered

The question which I put to you at first,

So I repeat it. Is the picture like

The dead man? When perforce I nodded yes:

Is Mariamne like her brother? Does she

Look like the youth who died so shamefully?

Is she so beautiful all women hate her?

HEROD. And you?

JOAB.

First hear the comments of the others,

Who left their seats and now were standing with me

Around the picture. Laughing they exchanged

Suggestive looks with Antony and said:

Say yes! if ever he befriended you,

Then you will see at least that he's avenged!

I said however that I did not know,

For I had never seen the Queen except

When she was veiled, and that is really true!

Herod (aside). Ah, Mariamne! But-I laugh at that;

For I shall know how to protect myself

From that, somehow, however it may come!

(to Joab) What message did he give to you for me?

JoAB. Why none! If I had had a message for you

I would not need to tell you all of this.

But now I thought I must! HEROD.

It's well! You shall

Return at once to Alexandria

With me and must not leave the royal palace.

JOAB. I shall not even talk to anyone.

HERoD. That I believe! For no one likes to die

Upon the cross while figs are ripening!

The dumb man shall be slain and should he ask

The reason, say to him: Since you can ask!

(to himself) And now I know through whom that wily serpent

So often learned what I-A wicked woman!

(to Joab) Take care of that! I want to see his head,

I plan to send it to my mother-in-law! 
(aside) She needs a sign of warning as it seems.

JoAB. At once!

HEROD. One other thing! The Galilean

Shall take his place, Zerubbabel's son Philo,

I want to speak with him before we leave. (exit Joab)

\section{SCENE 2}

Higrod (alone). Now comes the test! Once more! I almost said,

But I can see no end. I'm like the man

They tell of, whom the lion seized in front,

The tiger from behind, and whom the vultures

With beaks and talons threatened from above,

While he stood on a nest of vipers! Good!

I shall defend myself as best I can

Against each enemy with his own weapons,

260

Let that from now on be my rule and law!

How long it lasts, that shall not worry me

If I but hold my ground until the end

And lose no thing that I have called my own,

Then let the end come now, or when it will!

265

\section{SCENE 3}

SERVANT (enters). The Queen! (Mariamne follows him)

HEROD (goes to meet her). You steal a march on me, I was

About to-

MARIAMNE. Not to come yourself to get

The thanks I owe you for your wondrous pearls?

I have refused to see you twice, to try

Again to see if I had changed my mind,

That would have been too much for any man

And certainly too much for you, a king.

$\mathrm{O}$ no, I know my duty and since you

Have heaped rich gifts upon me every day

Since my gay brother's sudden death, as if

You're wooing me anew, so now at last

I come to show you my appreciation.

HEROD. I see!

MARIAMNe. Of course I do not know just what

Your purpose is. You send the diver down

For me into the sea's dark depths and when

No diver can be found who will disturb

Leviathan's repose for money wage,

You open up your jails and give the robber

His head again, which he had forfeited,

That he may serve you fishing pearls for me.

HEROD. And does that seem absurd to you? Why once 
I had them take a murderer from the cross, When there was need to save a child from flames That threatened it, and said to him: If you Can bring it safely to its mother, I

Agree the debt you owe to death is paid.

He plunged at once into the flamesMARIAMNE. And did he

Come out again?

IIEROD.

It was too late. I would

Have kept my word and would have sent him off

To Rome to fight, where they have need of tigers.

It's best to make full use of everything,

I think, why not of lives thus forfeit?

For cases do arise where one can use them.

MARIAMNE (aside). Oh, would he did not have the bloody hands!

Best say no more! Whatever he has done

Seems good when once he comes to speak of it.

How frightful it would be, if he compelled me

To find my brother's murder necessary,

Yes, unavoidable and justified!

HIRROD. So silent?

MARIAMNE.

Shall I speak? Of pearls perhaps!

Till now it was alone of pearls we spoke,

Of pearls which are so pure and clean and white

That even in bloody hands they never lose

Their lucid splendor! You are giving me

Great heaps of them.

H.EROD.

MARIAMNE.

It troubles you?

You surely can not wish to pay a debt

With them, and it would seem to me I have

A perfect right as wife and queen to pearls

And jewels. It is quite right for me to speak

Of precious stones as Cleopatra did:

They are my servants and I pardon them

That they cannot outshine the stars for me,

In spite of that they do surpass the flowers!

You have a sister, though, Salome-

HEROD.

MARIAMNE. Well, if you aim to have her murder me,

Then keep right on, despoil the sea for me,

If not, then give the diver respite! I stand

Already deep enough in debt to her!

You seem to doubt? I lay a year ago

Quite sick and close to death, she kissed me then.

It was the first and only time. I thought

At once: The kiss is your reward, because

You are about to die! And so it was; 
But she was disappointed, I recovered, And now I have her kiss for nothing; that

She never has forgotten. So I fear

That she might think of that, if I should go

To see her with the pearls around my neck

By which you showed me last how much you love me!

HEROD (aside). The only thing that still is lacking is

That my left hand should turn against my right.

MARIAMNE. I would at least disdain the drink of welcome;

If she should offer me instead of wine

A drink of water in a crystal glass,

I still would leave the water quite untouched:

Of course that would not mean a thing! No! That

Would even be quite natural, for water

Seems to me no longer what it was:

A gentle element that waters flowers,

Refreshes me and all the world; it sends

A shudder through me, fills me now with horror,

Since my own brother died so suddenly;

I always think, within the drop dwells life,

But in the wave there dwells a bitter death;

For you it must be very different!

HEROD.

Why?

MARIAMNe. Because you have been slandered by a river

Which dares unload its own inhuman and

Malicious deed on you; but never fear,

For I dispute it!

HEROD.

Really?

MIARIAMNE. I can do it!

To love the sister and to kill the brother,

The two can not be reconciled. HEROD.

Perhaps!

If such a brother is himself intent

On killing, and if one can only save

Himself by matching him, yes acting first!

We're speaking here of possibilities!

And further! If he, unsuspecting, lets

Himself become a weapon in the hands

Of foes, a weapon which must strike and kill,

If not destroyed before it has been swung.

We're speaking here of possibilities!

And if it threatens not a single head-

$\mathrm{No}$, if it is the head of all the people

And one as necessary to this people

As ever any head to any body.

We're speaking here of possibilities!

I think in all these cases that the sister,

As wife because of love she owes her husband, 
As daughter of her people out of sacred

Duty, as queen because of both of these,

Must say: I dare not censure what has happened.

(he takes Mariamne's hand)

Although a Ruth might well not understand me-

How would she learn it plucking ears of grain-

A Maccabee will surely comprehend!

You could not kiss me there in Jericho

But surely in Jerusalem you can!

(he kisses her) And if this kiss should rue you nonetheless,

Then listen, and you will be reconciled:

I took the kiss as my farewell to you

And it may be, this parting is forever!

MARIAMNE. Forever?

HEROD.

Yes! For Antony has summoned

Me. Whether I return, I do not know!

Mariamne. You do not know?

FiEROD.

Because I do not know

How harshly my-your mother has accused me.

MARIAMNE (starts to speak).

HEROD. It makes no difference! I shall find it out.

But one thing I must know from your own lips:

Whether and how I shall defend myself.

MARIAMNE. Whether-

FEROD.

Oh Mariamne, do not ask!

You know how strong the bond that holds me to you,

You know that every day but makes it stronger,

And you must surely realize, I now

Can not fight for myself if you do not

Assure me that your heart still beats for me!

Oh tell me whether ardently or coldly,

Then I will tell you whether Antony

Will call me brother, or perhaps condemn

Me to the subterranean dungeon where

Jugurtha died the death of slow starvation!

Why are you silent? Speak! For this confession

Does not, I feel, beseem a king; he should

Not be subjected to the common lot

Of man, should not be bound within himself

To any being that's outside of him,

He should be bound to God alone, and I

Am not! When you a year ago lay sick

And at the point of death, I had the thought

That I would kill myself. I could not bear

To live if you were dead-you know this now,

So know one other thing! If ever I

Myself lay dying I could even do

What you expect Salome would, prepare 
A poison in your wine and give it to you,

So I should still be sure of you in death!

MARIAMNE. If you did that, you would no doubt recover!

HEROD. Oh no! For I would share this poison with you!

But tell me whether you could e'er forgive

Such an excess of love as that would be!

MARIAMNE. If after drinking such a drink I still

Had only breath enough for one last word,

Then I would curse you with that final word.

(aside) Yes, all the more, the more I'm sure that I

Could reach out for the dagger in my grief

To kill myself if death should call you hence:

That one can do, not have it done to him!

Herod. In this last night a fire consumed a woman

With her dead husband; and although they tried

To save her, she resisted. You probably

Despise this woman then?

MARIAMNE.

Who says I do?

She was not forced to be a sacrifice,

She sacrificed herself and thus she proved

The man meant more to her than all the world.

HEROD. And you? And I?

MARIAMNE.

If in yourself you feel

That you mean more to me than all the world,

What else is there to keep me in the world?

HEROD. The world! The world still has so many kings

And there is none among them who would not

Be glad to share his throne with you, would not

Desert his bride, cast out his wife for you,

And had the wedding been the night before!

MARIAMNE. Is Cleopatra dead, that you speak so?

HEROD. You are so beautiful, whoever sees you

Has to believe in immortality,

Of which the Pharisees so glibly speak,

For none believes your image ever could

Die out in him; so beautiful I should

Not be surprised if suddenly the mountains

Provided me a metal to adorn you

More precious far then even gold or silver,

A metal kept reserved until you came;

So beautiful that-Ah, to know you'll die

From love, the moment that another dies,

To hasten after him who went before,

To mingle in that sphere in which one is

And yet is not, for so I think of it,

As your last breath and his last breath together-

That would be worth a voluntary death,

Would mean to find a bliss beyond the grave 
Where horror dwells: oh, may I, Mariamne, Perhaps still hope for this, or must I fear

That you-for Antony has asked about you!

Mariamne. One does not ask a promissory note

On deeds, much less on pain and sacrifice,

Such as despair, I feel, may bring, but which

Love never can demand!

HEROD.

Farewell!

MIARIAMNE.

Farewell!

I know you will return; for He alone

Decrees that you shall die!

HEROD.

So little fear?

MARIAMNE. So great assurance!

HEROD.

Love is ever anxious!

It trembles even in the hero's breast!

MaRiamne. Mine trembles not at all!

HEROD.

You do not tremble!

MARIAMNE. Now I begin! If you can trust no more

Since you contrived my brother's-Then alas

You do not give your word,

Your simple word, when I had hoped to have

A vow from you; on what shall I depend?

Mariamne. And if I made it, what is ycur assurance

That I would keep it? Only I myself,

My nature as you know it. So I think,

Since you must end with hope and trust in me,

You might as well begin with both of them!

Go! I can not do otherwise! Not yet! (exit)

\section{SCENE 4}

HEROD. Not yet! Tomorrow or some other day!-

She plans to do me favors after death!

A wife speaks so? Of course I know that often

When I had called her beautiful, she twisted

Her face awry till she no longer was,

I know she can not weep, and spasms are

For her what tears for others! I also know

She quarreled with her brother not so long

Before he met his death while in the bath

And afterwards would not be reconciled;

Yes, more than that, when he already was

A corpse, a gift was brought from him which he

Had bought for her while on his way to bathe.

Yet does a wife speak so, and at the moment

The man she loves, or surely is at least 
Supposed to love - - She is not turning back,

As once, when I - She left no scarf behind

As pretext - - No, she can endure to have

Me leave with this impression - - Very well!

To Alexandria-the grave-no matter!

But one thing first! One! Earth and Heaven listen!

505

You made no vow to me, but I make one

To you: I place you now beneath the sword!

If Antony puts me to death for you,-

And for your mother's sake he will not do it!-

He but deceives himself; though it is doubtful

Whether the clothes that cover me at death

Will follow to the grave, because a thief

May rob my corpse, yet you shall follow me!

That is my vow! If I do not return,

You perish! That command I leave behind!

515

Command! But that presents a vexing problem;

How to assure myself obedience

When I am feared no more? Oh, someone will

Be found, I think, who has good cause to be

In fear of her!

\section{SCENE 5}

Servant.

HEROD.

Your brother-in-law!

That is my man! I will give him my sword

And then by working on his cowardice

Incite his courage to the point of using it!

JCSEPH (enters). I hear you think of setting out at once

For Alexandria. I wish Godspeed!

HEROD. I leave at once. May be, not to return.

JOSEPH. You fear that you will not return?

HEROD.

JOSEPH. You never talked like this before!

HEROD.

I might not!

Assured, things never looked so bad for me!

JOSEPH. If you are losing heart-

HEROD.

But I am not,

For I shall bear whatever comes, but hope

Is gone that any good may come of it.

JOSEPH. I only wish that I had been quite blind

And never had laid bare the secret plans

Of Alexandra!

HEROD.

That I can believe!

JosEPH. For if I never had found out that she

Had had Aristobulus' portrait painted

Quite secretly for Antony, and if 
I had not learned that she sent messages

To Cleopatra, and then last of all

I had not seized the coffin in the harbor,

Which hid her son and her, and stopped their flight

When it had scarce begun-

HEROD.

Then she would have

Nothing to thank you for, and you could calmly

Stand by and see her daughter on the throne,

Which Mariamne, daring Maccabee,

Will surely seize if I do not return,

And if no other seizes it before her.

JosepH. I do not mean that. I mean, many things

Would never have been done!

HEROD.

Yes, that is right!

But other things would have occurred instead.

That makes no difference-You recounted much,

One thing you have forgotten!

JOSEPF.

What is that?

HEROD. You too were in the bath when he-

JOSEPH.

I was!

HEROD. You wrestled with him too?

JOSEPH.

HEROD. Well then!

JOSEPH.

The dizzy spell had not yet seized him

While I was with him, if it had come on,

I would have rescued him, or else he would

Have pulled me down with him beneath the waves.

HEROD. I have no doubt of that. But you must know

That no one who was there speaks otherwise,

And since an evil chance decreed that you

Not only went into the water with him

But wrestled with him too-

JOSEPH.

Why do you stop?

HEROD. My Joseph, you and I, the two of us,

We are accused!

JOSEPH.

I too?

HEROD. You are not only

My brother-in-law, you are my friend as well!

JOSEPH. I hope I am!

HEROD.

Oh had you never been!

Had I, like Saul, but thrown the spear at you

And you could prove it by your gaping wounds,

It would be better for you, then this slander

Would not have found a willing ear, nor would

You be beheaded for a bloody deed

You never did commit!

JOSEPH.

What, I? Beheaded?

HEROD. That is your lot if I do not return 
And Mariamne-

JOSEPH.

I am innocent!

HEROD. What help is that? Appearances are bad!

And even if they did believe, are not

The many many services that you

Have done for me, in Alexandra's eyes

580

A proof of crimes against herself, will she

Not think: If he had let me flee, then he

Who now lies in the grave would be alive?

Joseph. True! True!

HEROD. Can she not therefore with a sort

Of right demand your life to pay for one

That she believes she lost through act of yours,

And will she not demand it of her daughter?

JOSEPH. Salome!. This has come because I went

To see the painter! Every year she wants

A portrait of me!

HEROD.

I know how she loves you!

JoSEPH. Ah, if she loved me less it would be better!

Would I have found Aristobulus' portrait,

If I-Salome, you can now soon have

My last one, but it will be headless!

HEROD.

Joseph,

One must defend his head!

JOSEPH.

If you admit

Your head is lost?

HEROD.

I do not quite do that,

I still shall try to save it if I can,

By putting it into the lion's jaws

Quite voluntarily.

JOSEPH.

In that you once

Succeeded when the PhariseesHEROD.

But now

The case is worse, whatever comes to me,

Your fate I leave with you in your own hands;

You always were a man, be now a king!

I hang the purple mantle round you, extend

To you the scepter and the sword, so hold

Them fast and give them back to me alone!

Joseph. But do I hear aright?

HEROD.

And to assure

Possession of the throne and of your life,

Kill Mariamne, if you ever hear

That I am not returning.

JOSEPH.

Mariamne?

HEROD. She is the only bond that Alexandra

Has with the people since the river drowned

Her son, she is the brightly colored crest 
Rebellion will be sure to wear if it

Rise up against you.

HEROD. You are astonished-I am not dissembling,

And my advice is good, is good for you,

What need for futher words? Yet it is not

Alone for you-In plain words: I can not

Endure the thought that any other ever-

That would be bitterer than-she is proud

I know-yet after death-an Antony-

And then above all else this mother-in-law,

Who will incite the dead against the dead - -

You understand!

JOSEPH.

But-

HEROD.

Hear me to the end!

She let me hope that she would kill herself

With her own hand, if I-One has the right

To have a debt collected?-One may even

Use force to-What do you think?

JOSEPH.

I believe so!

HERoD. Then promise me that you will kill her, should she

Not kill herself! Do not be overhasty,

But do not wait too long! So go to her

As soon as messengers, for I shall send them,

Report to you that I am dead, and tell her;

Then notice if she reaches for a dagger,

If she does something else. You promise?

HEROD. I will not have you swear an oath. There is

No need to have one swear that he will crush

A serpent that is threatening him with death.

$\mathrm{He}$ does it of himself, if he is sane,

Since he could leave off taking food and drink

With much less danger than omitting this.

$$
\text { (Joseph moves nervously) }
$$

I know you well! And I will recommend you,

Tell Antony you are the only one

Whom he may trust. That you will prove to him

By showing him that even blood relations

Are not too sacred for a sacrifice

If there is need to stop a revolution.

That is the explanation for the deed

Which you must give him. Street rioting

Will surely follow it, and you must tell him

That rioting preceded it as well,

Which only was subdued by killing her.

And as concerns the people, they will shudder

When they behold your bloody sword, and many 
Will say: I knew this man but half! And now-

JosepH. Until we meet again! Today is not

The end! I know you will return, as always.

HEROD. A possibility, so one thing more! - - (long pause)

I swore an oath just now concerning you!

660

(he writes and seals)

It is recorded here! Take this sealed sheet!

You see it is addressed to-

JOSEPH.

To the hangman!

HEROD. And I shall keep what. I have promised in it,

If you should tell a tale about a king

Perhaps, who gave-

JOSEPH.

Then give the order to me

To take this sheet myself straight to the hangman! (exit)

Herod (alone). She lives beneath the sword, and that will spur me

To do what I have never done, to bear

What I have never borne, and comfort me

If it is all in vain. And now, away!-(exit) 


\section{ACT II \\ Castle Zion. Alexandra's rooms.}

\section{SCENE 1}

\section{Alexandra and Sameas.}

Alexandra. And now you know this!

SAMEAS.

I am not surprised!

Nothing that Herod does surprises me!

For one, who as a youth declares a war

Against the Sanhedrin, with naked sword

Steps up before his judge and gives him warning

That he himself is hangman, and the hangman

Will carry out no sentence on himself,

He may as man - - Ah, I can see him yet,

How he, undaunted by the high priest, leaned

Against a column with his soldiers round him,

Those soldiers who in chasing down the robbers

Themselves had been transformed to robbers too,

And calmly counted us all, one by one,

As if he stood before a bed of thistles,

And were deciding how to clear it out.

Alexandra. Yes, yes. it was a moment made for him,

On which he may quite well look back with pride!

A youthful madcap, scarcely twenty years

Of age, is summoned by the Sanhedrin,

Because, in criminal excess of spirits,

He has presumed to go against the law,

Because he dared to carry out a sentence

Of death which you had not as yet decreed.

The widow of the dead man, with a curse,

Has met him on the threshold, and within

Sit all Jerusalem's old men and gray beards.

Because he has not dressed in sackcloth, has

Not strewed his head with ashes, you lose courage.

You think no more of punishment for him,

You do not even think of threatening him,

You do not speak a word, he laughs and goes!

SAMEAS. I spoke!

Alexandra. It was too late!

SAMEAS. If I had spoken

Sooner, it would have been that much too soon,

Respect for the high priest had kept me silent,

The first word was for him, for me the last,

He was the oldest there, the youngest I!

Alexandra. Mere words! If then and there you Sanhedrists Had proved the simple courage of your duty, 
No greater courage would be needed now!

But now see whether you - $-\mathrm{Oh}$, you will find

Some other good excuse, I know! If you

Are not inclined to fight with him-in fact,

It would be venturesome and I advise

Against it-then you only need to fight

With lions or with tigers when he orders.

715

SAMEAs. What's that?

ALEXANDRA. You know the gladiatorial combats,

The Roman games?

Sameas. Praise God, I know them not!

I think it is a gain to know what Moses

Tells us about the Gentiles, nothing else;

I close my eyes quite tightly every time

720

A Roman soldier meets me on the street,

And I still bless my father in his grave

That he had never taught their tongue to me.

ALEXANDRA. You do not know they bring wild animals

To Rome, which they have sent from Africa

725

By hundreds?

Sameas. No, I had not heard of that.

ALEXANDra. That in the stone arena there they drive

Them all together, that they then send in

Their slaves to them, who have to fight with them

Till men or beasts are dead, while they themselves

730

Sit round them in the amphitheater

And shout with joy when mortal wounds are gaping,

And when the bright red blood spurts on the sand?

Sameas. The wildest of my dreams has never shown

Me that, and yet it fills my soul with joy

To learn of it, it is well suited to them!

(with hands upraised)

Lord, Thou are great! Though Thou dost grant the Gentile

The right to life, yet he must pay Thee tribute,

A fearful tribute for it too, for he

Is punished by the very way he lives it! -

How I should like to see those games!

ALEXANDRA.

Your wish

Shall be fulfilled when Herod has returned,

He thinks of introducing them!

SAMEAS.

Oh, never!

ALEXANDrA. That's what I said! And why not? For we have

Lions a plenty! And the mountain herdsman

Rejoices if their number but grows less,

For that will save him many cows and calves.

SAMEAS. But quite aside from all the rest, where would

He find the fighters? There are no slaves with us,

Who owe him service even unto death. 
Alexandra. The first-I see before me!

SAMEAS.

What?

ALEXANDRA.

Of course!

You will distort your face as you do now,

Perhaps will even tightly clench your fists,

Will roll your eyes and gnash your teeth with rage

When you shall live to see the day on which

755

He dedicates the heathenish arma

As festively as Solomon the Temple.

All that will not escape him, as reward

He will command you by a sign to enter

And show the people there what you can do,

760

When you are thus confronted with a lion

That has been kept from food for many days.

For since we have no slaves, the criminals

Deserving death will have to take their place,

And who then is deserving death, if he

765

Is not, who openly defies the King!

SAMEAS. He could-

ALEXANDRA. Oh, do not doubt! It would be bad

If they should take his head from him too soon,

Then there would die with him such mighty plans

As even Pompey, who with impious boldness

770

Once dared to penetrate the Inner Temple,

Perhaps-

Sameas (bursting out). Oh Antony, if you destroy him,

Then for a whole year long I will not curse you,

And if you do not-well then, we are ready!

ALEXANDRA. He thinks that if our people were intended

To keep from mixing with the others, God would

Have given us the world all for ourselves!

SAMEAS. Does he think that?

AleXANDRA.

Since that is not the case,

He thinks that there is need to break the bars,

Which separate us still from all the rest,

As dykes cut stagnant pools off from the sea.

And that could happen, if we would adapt

Ourselves to them in usage and in customs.

Sameas. In usage-(to Heaven) Lord! If I am not to go

Completely mad, show me how he will die!

Show me the death that borrows all the horrors

From every other death, and then proclaim

To me, it is for Herod this is done!

ALEXANDRA. Then be yourself death's angel!

SAMEAS.

For myself,

If not for him! I swear! I will prevent

This outrage or will punish my own weakness

And kill myself (with a motion toward his breast) 
before the day arrives

Which is besmirched by such abomination!

That oath compels me to commit a crime

If I can not perform heroic deeds;

795

What man is there who ever swore a greater?

ALEXANDRA. Good! But do not forget, if your own arm's

Not strong enough to overcome the foe,

Do not reject with scorn the arms of others!

SAMEAS. These others?

AlEXANDRA.

You can arm them easily!

SAMEAS. Explain your words!

Alexandra.

Who gave the royal crown

To Herod?

SAMEAS. Antony! Who else than he?

ALEXANDRA. Why did he do that?

SAMEAS.

Because he liked him!

Or merely this, because we did not like him!

When has a Gentile had a better reason?

AleXANDRA. Another thing! What keeps him on the throne?

Sameas. The people's blessing, no! Perhaps its curse!

Well, who can say?

AlexandRa.

Why I! The trick alone

Of sending in the tribute we must pay

The Romans every year, before it's due,

And even freely doubling it unasked,

If somewhere a new war has broken out.

The Roman wants our money, nothing more,

He lets us keep our ancient faith, our God,

And he would even honor Him with us,

Grant Him that place upon the Capitol

Beside his Jupiter and Ops and Isis,

Which is unoccupied until today,

If $\mathrm{He}$, like them, were only made of stone.

SAMEAS. If that is so, and I regret to say

It is, what do you hope from Antony?

In this respect, as you yourself have said,

There's nothing Herod leaves undone. Just now-

I saw him go! The back of one mule broke

Before it even reached the city gate!

For every drop of blood within his veins

He offers him an ounce of gold; do you

Believe he will reject the gold for you?

ALEXANDRA. Of course not, if I acted for myself!

But Cleopatra works in my behalf

And Mariamne helps me too, I hope.

You are surprised? I do not mean in person,

She is more apt herself to work against me,

But through her portrait, and not even that, 
No, through another which resembles her.

For as the forest shelters not alone

The lion but his foe the tiger too,

There nestles also in this Roman's heart

A swarming serpent-brood of fiery jassions

Which struggle with each other for control,

And if now Herod builds upon the first,

Then I build on the second, and I thirk

The second one is stronger than the first.

SAmeas. You are-

AlEXaNDRA. No Hyrcanus, although his daughter!

But lest you should misjudge what I have done,

Know this: I am no Mariamne either!

If Antony destroys the husband, who

Possesses her, to clear the way to her:

She still is mistress of herself and can

Entrench herself behind her widow's veil.

But I am certain of one thing: already

His hand is on his sword, and if he has

Not drawn it, only this consideration

Has really held him back: the Romans think

This lucky soldier Herod is the ring

Of iron holding things together here.

Just bring the proof the opposite is true,

Stir up revolt, disturb this lazy peace,

Then he will draw it!

SAMEAS.

That will be quite easy!

In thought the people have already slain him

And it is said-

Alexandra. So put your seal upon it,

And quickly then disclose his testament!

You know its contents now, the Roman games

Stand first in it, and if each one believes

He will receive a hundred lashes less

865

By Herod's death, or miss the martyr's cross,

Then each one thinks, what he is right in thinking.

For Israel is facing things so terrible,

That it may force from many hearts the wish

Of utter desperation, that the Red Sea

Had swallowed all the people, all twelve tribes

Of Israel, and Moses first of all.

SAMEas. I go! Before the noontide comes-

AlexandRa.

I know

What you can do when you put sackcloth on

And, shouting woe! alas! move through the streets

As if your forebear Jonah were among us.

And you will learn that it is very useful

To go sometimes to see the fisherman, 
And eat that humble tradesman's food that he

Permits himself because no one has bought it.

880

Sameas. And you yourself will learn, we Pharisees

Have not forgotten the disgrace we suffered,

As you seem to believe. So listen now

To something you were not supposed to learn

Until it happened: we are sworn long since

885

Against him, all Judea's undermined

And in Jerusalem, so you will see

How firmly we can count upon the people,

There even is a blind man in our league.

AlEXANDRA. What use is he?

SAMEAS.

Why none! And that he knows!

But yet he is so filled with hate and anger,

That he would rather share the undertaking

With us and die, than still continue living

In such a world, if it should not succeed.

I think we may consider this a sign. (exit)

\section{SCENE 2}

Alexandra (alone). In thought the people have already slain him!

I know! I know! And I can see by that

How much they wish he never will return.

How fortunate that as he left the swarm

Of locusts hid him from our sight, for that's

An omen that they do not wish in vain.

And it is possible that even now

He is beheaded.-No, speak as you think,

No Pharisee is lurking at the door!

And Antony is Antony, I know,

$\mathrm{He}$ is a Roman too, and Romans form

Their judgments slowly, execute them swiftly.

He may now be a prisoner, although

Not yet in prison! If one uses that,

It can lead further. Therefore it is good

If insurrection comes, although I know

What insurrection means, no less I know

What consequences it will have if he

Returns in spite of all. If! That can happen,

So weigh it well! Before he left, he sent

A severed head as parting gift to you.

That shows-Fie! I am talking like my father!

That shows me he is swift as tyrants are,

And also that he aims to frighten me.

The first I knew long since, the other shall not

Succeed! And if the very worst should come,

If everything I try should fail, if he 
Should dare the worst in spite of his strong love For Mariamne, which will rather mount Than fall, and will protect me if she will-

What of it? I have ventured all for vengeance, In death it would be vengeance still, on him Who did it and on her who let it happen. The people, even Rome itself, would not Look on at it with patience. As for me, I should be better suited to my forebears If death for me should be a bloody one! Did not the great-grandfathers of my race, The great-grandmothers too, did not the most Of them go to the grave without their heads

Because they would not bow them? I should share Their lot with them, what more then would it be?

\section{SCENE 3}

\section{Mariamne enters.}

Alexandra (aside).

She comes! Yes, if she could be turned from him

And could be moved to follow me to Rome,

Then-But, she hates him and she loves him too!

Shall I still dare a last attack? So be it!

(she hastens up to Mariamne)

You seek for comfort where it can be found!

Come to my heart!

MARIAMNE.

Comfort?

Alexandra.

You feel no need?

I have misjudged you then! But I had reasons

For thinking you the sort of wife you are not,

And what I heard was slander!

MARIAMNE.

What you heard?

ALEXANDRA. They told me of embraces and of kisses

You gave your fratricidal husband right

After the murder-Do forgive, I should

Not have believed it.

MARIAMNE.

No?

ALEXANDRA. No, never, never!

For more than one good reason! Even if

You could have turned so heartlessly aside, Refused to give your brother's bloody shade

A sister's offering of revenge, which you

Could take, not by a Judith's sword, nor yet

By Rahab's nail, but merely by a twist

Of lip or silent crossing of your arms,

And should have taken for the dead man's sake:

The murderer himself would not have dared 
Approach, for you resemble so the dead man,

You would have seemed to him too like the corpse,

Aristobulus' corpse, made up with rouge.

He would have turned away from you and shuddered.

MARIAMNE. He did not do the one, nor I the other!

ALEXANDRA. Then be-But no! Perhaps some doubt remained

As to his guilt. Do you want proof of it?

MARIAMNE. I need no proof!

ALEXANDRA.

MARIAMNE.

You -

It is not important!

ALEXANDRA. Then-But I hold the curse back even now,

For you are laden with another cne!

You still are bound in fetters by a love

970

Which never brought you honor.

MARIAMNE.

But I thought,

I did not choose my husband for myself,

I but submitted to the lot which you

And Hyrcanus deliberately imposed

On me, the grandchild and the daughter.

AlexANDRA.

Not I

975

But my faint-hearted father planned the marriage.

Mariamne. Then what he did displeased you?

ALEXANDRA.

No, it did not!

For then I would have fled with you before-

A refuge had been offered me in Egypt.

I only say that he evolved the plan,

The first of all our high priests lacking courage;

I merely fought the feeling of aversion

With which I heard the plan at first. But still

I did it, for I liked the coward's deal

On second thought, and gave the pearl of Zion

For Edom's sword, when he insisted on it!

Yes, if the serpent had been poisonous

That at the time had bitten Cleopatra,

Or if Mark Antony, when on his journey,

Had only come this way, why then I would

Have answered no! As 'twas, I answered yes!

MARIAMNE. And yet-

ALEXANDRA. I had expected that you would

Not merely waste the purchase price, I hoped

That you would ask of Herod-

MARIAMNE.

Oh, I know!

I should have made him pay for every kiss

By granting me a head that you disliked,

And finally when no one more defied you

Save only he himself, have driven him

To suicide, or if that did not work,

On some still night I should have craftily 
Repeated Judith's sneaking deed on him;

That would have made you proud to call me daughter!

Alexandra. Much prouder, I do not deny, than now.

MARIAMNE. But I preferred to be a wife to him

1005

To whom you married me, for love of him

Forget I was a Maccabee, as he

Forgot that he was king for love of me.

ALEXANDRA. In Jericho, however, you again

Remembered it, or so it seemed, at least

You were the first who openly accused him

1010

While I myself held back with my complaint,

To test you. Am I right?

MARIAMNE.

In Jericho

The terrible event confused me so,

It came too suddenly, from meal to bath,

From bath to grave, a brother, I admit

1015

My brain reeled! If, however, stubborn and

Suspicious, I closed my door to king and husband,

I'm sorry now and can forgive myself

Only because it happened as in fever!

ALEXANDRA. In fever!

MARIAMNE (half to herself). I would not have done it either

If he had not worn mourning when he came!

In red, in deep dark red, I could have seen him,

But-

Alexandra. Yes, he found it quickly! He had ordered

It in advance, as other murderers

Draw water, possibly, before they murder-

MARIAMNE. Mother, do not forget!

AlexandRa.

What? That you are

The murderer's wife? That's something you've become,

And only are as long as you desire,

Perhaps right now, who knows! you're that no longer;

But yet you always were the dead man's sister

And that you will remain, you even still

Will be, if you-you seem inclined to do it -

Should shout into his grave: It serves you right!

MARIAMNE. I owe respect to you, I should not like

To do it violence and, therefore, stop!

For otherwise I could-

ALEXXNDRA.

What?

MARIAMNE.

Who is more guilty of it, whether it's

Ask myself

The man who did the deed because he had to

Or she who drove him to it! Let the dead rest!

AlexandRa. Then speak to one who did not give him birth!

I carried him beneath my heart, and must

Avenge him, since I can not waken him, 
That he avenge himself!

MARIAMNe. Avenge him then,

Avenge him on yourself! You know full well

That as high priest, surrounded and acclaimed

10.45

So by the mob, his head turned by the honor,

Not as the heedless youth Aristobulus,

He brought upon himself the thing that happened.

Now tell me who it was that stirred him up

And made him lose his self-complacency!

1050

He had no lack of gaily colored clothes,

That so attract the eyes of pretty girls,

He had no need of more to make him happy.

What need had he of Aaron's jriestly mantle,

Which you draped round him as an added glory?

1055

He had himself no other thought about it

Than this: Is it becoming to me? Others,

However, from the moment that he donned it,

Thought him the second head of Israel

And you soon managed so to turn his head

1060

He thought himself the first and only one!

AlexandRa. You slander him and me.

MARIAMNE.

Oh no, I do not!

If this gay youth who seemed to have been born

To be the first completely happy person,

If he so quickly met a gloomy fate,

And if the man who makes all other men

Rank cowards if he draws his sword, if he-

I do not know he did it, but I fear it;

Then lust for power and ambition are

To blame, not the ambition of the dead man

And not the lust for power of the King!

To lay the blame on you would not-be seemly;

I do not ask that you should shed a single

Repentant tear because you sent a ghost,

A bloody ghost, into our wedding chamber,

Although we two no longer are alone,

And now the third disturbs my mind so much

That I am silent when I ought to speak

And speak when it were better to be silent.

I will not even try to quench your zeal

For vengeance, will not ask what you avenge,

Whether it is your plans or is your son:

Do what you will, go on, or call a halt, But be assured that if you strike at Herod

You strike at Mariamne too; the oath

That I refused, when he demanded it

On parting, I will swear it now: I die,

If he should die. So act and say no more! 
Alexandra. Then die! And now! ForMariamne. Oh, I understand you!

And that is why you thought I needed comfort?

Oh no! You're wrong! I do not feel alarm

If menial mobs, which only tolerate

The chosen few because they're human, mortal,

Already have put him to death with words.

What else is there a slave can do, whene'er

1095

A king goes by in regal pomp and splendor,

Than say: His turn will surely come, like mine!

I do not grudge him that! and if he moves

A battlefield with many graves up close

Beside the throne, I quite approve of that,

It stifles envy! Yet my heart tells me

That Herod lives and will live. Death must cast

A shadow, it falls here, inside!

\section{SCENE 4}

Servant.

The Viceroy!

Alexandra. And surely armed, just as he always is,

Whenever he comes to see us, since he failed

To dupe us by the use of flattery,

As seemed to be his aim when first he came.

Do you know that Salome almost died

Of jealousy of you?

MARIAMNE. She still is jealous!

For constantly, when she is near, I tell him

The worst things, smiling intimately,

And since she never wearies of her spying,

I do not weary either, plaguing her

Because she is so foolish!

Joseph enters.

AleXandra (pointing to his weapons). See!

MARIAMNE. Oh let him!

His wife demands it so that she can dream

She has a valiant and courageous husband.

AleXANDRA (to Joseph).

I am still here, you see!

JOSEPH.

A strange reception!

Alexandra. My son is still here too! He has again

Concealed himself within a dead man's coffin.

If you will drive him forth, I will forgive you

For having done it once before unbidden.

But this time you must seek the coffin, not

On any ship that sails the sea to Egypt,

But deep within the bowels of the earth!

JOSEPH. I am not one who can awake the dead! 
Alexandra (scornfully to Mariamne).

How true! For then you would have gone to Egypt

To help your master when he kneels and pleads

And that does not protect him from the axe-

MARIAMNE. He kneel and plead!

JOSEPH (to Mariamne). And I can show you how!

"I am accused of this!" Yes, I admit it.

1130

"But not of this!" I add it right at once

So that you know it all! He'll do it so.

Alexandra. You boast for him?

JOSEPH.

He did that once before!

I stood beside him, when the Pharisees

Had planned to file a charge with Antony.

1135

He hastened on to camp ahead of them

Just as he was, told it himself instead,

And when they came, repeating all the charge,

Enlarging point by point, he said: Now speak!

Have I omitted anything or not?

1140

You know the end, how many an accuser

Then lost his stubborn head for not retracting;

He had the Roman's favor when he left.

ALEXANDRA. The two were younger then than they are now.

The arrogance of Herod pleased the other,

And all the more, since others bore the cost

Not he himself. The Pharisee whose tongue

Is always preaching of revolt 'gainst Rome,

Can he be anything? Whoever plucks

His beard for him, reduces his esteem!

Thus Antony did think and laugh, I doubt

That he will let that happen to himself!

JoSEPH. You speak as if you wished-

AlexandRa.

Whether we wish

Alike or not is no concern of yours!

Hold your wish fast! For you it is important

That he return!

JOSEPH.

You think so? If for me,

Then too for you!

ALEXANDRA.

I know no reason why!

There was an Alexandra once before

Who came to wear a crown in Israel,

Who seized it when no king was wearing it

And did not leave it for a thief to steal.

By God, there soon shall be a second one

If there are really (to Marianne) Maccabean women

Who keep their childish oaths!

JOSEPH (listening).

Yes, it is true!

There really was once such an Alexandra,

But if one will attain her goal, he'll have 
To follow her example to the full,

Not merely half. She reconciled herself

With all her foes when once she took the throne,

Now no one feared her more but only hoped,

1170

No wonder that she sat secure till death!

MARIAMNE. That is deplorable! Why have a scepter,

If not to satisfy both love and hate?

A twig's enough to scare away the flies!

Joseph. How true! (to Alexandra) And you?

1175

Alexandra.

She never saw in dreams

The father of her race, the mighty Judas,

Else she would not have feared a single foe,

For even from the grave he guards his children,

Because he cannot die in any heart.

How should he die! No one can ever pray,

Who does not have to say: It's due to him

That I may kneel before my God and not

Before a god of wood or stone or bronze!

JosePH (aside). The King was right! I must commit the deed,

Put both to death or suffer death myself.

I have to put the crown upon my head

If I would save it from the hangman's axe.

A world of hate stares at me here! So be it!

They have pronounced the sentence on themselves;

Now for the last time I have tested them,

And if his messenger were here, I would

This very moment do it without mercy!

My preparations are already made.

\section{SCENE 5}

SERvant. The Captain Titus asks an audience!

JoSEPH. At once. ( $\mathrm{He}$ is about to go)

ALEXANDRA. And why not here?

SERVANT. He's here already!

TITUs (enters; secretly to Joseph).

The thing you feared is happening, the people

Are in revolt!

JosePH. Then do what I commanded,

Draw up your cohorts and advance at once!

TrTus. That is already done. I come to ask:

Do you want prisoners or only dead men?

My eagle merely seizes, or it mangles,

And you must know which method suits you better.

JoSEPH. No blood must flow!

Trrus. Good! I shall then move in

Before the stoning starts, but otherwise

I should delay! 
JoSEPH.

Did you see Sameas?

TITUS. The Pharisee who one time almost crashed

His head against my shield because he shuts

His eyes each time he catches sight of me?

I saw him, to be sure!

JOSEPH.

And how? Speak loudly!

TITUS. With thousands round him in the open market

And loudly cursing Herod!

JoSEPH (to Alexandra). Sameas

Just left you! It was not an hour ago!

AleXANDRA. You saw?

Titus (to Joseph). You'll come yourself?

JOSEPH.

When I can!

And in the meantime-

Titus.

I am leaving! (turns to go)

ALEXANDRA (calls him back). Captain!

Why did you take away our guard? MARIAMNE.

The guard

Has gone?

Alexandra. Yes, yesterday!

JOSEPH.

I ordered it!

TITUS. Because the King told me before he went:

This is the man who knows just what I want,

What he commands, that I command myself! (exit)

Alexandra (to Joseph).

And you!

JoSEPH. I thought that Judas Maccabaeus

1220

Was guard enough for you and for your daughter.

And furthermore you hear how things are going:

I need the soldiers elsewhere! (aside) If the Romans

Were near, it might not be successful! Today

I sent the Galileans!

Alexandra (to Marianne). Do you still

Think my suspicion false?

MARIAMNE.

I do not know,

But it infects me now. I find this strange!

Although-If spears came flying from the wall

They would not come more unexpectedly!

Alexandra. Two dagger thrusts would clear the way for him;

For if there are no Maccabees alive,

Then the Herodians will claim the throne.

MARIAMNE. I should still laugh at you, were only

Salome not his wife!-But by my brother,

Her head is mine! And I will say to Herod:

As you give me revenge on her, just so

You love me! For it must be she, not he!

Alexandra. Do not rejoice too soon! First we must act,

And this revolt can serve our purpose well! 
Mariamne. I will not be involved in this revolt,

Because, if Herod does return, I have

Nothing to fear, and if he does not come,

Then I will welcome death in any form!

AleXANDRA. I'm going! (starts to leave)

JOSEPH (stepping in her way). Where?

ALEXANDRA.

Up to the parapet

For now, and after that where I may please!

JOSEPH. The way up to the parapet is open!

The fortress closed!

Alexandra.

So we are prisoners?

JOSEPH. Until the time when peace has been restored,

I must request you-

Alexandra.

Are you not presuming?

JoSEPH. A stone is blind, a Roman javelin too,

They both may hit what they are not supposed to,

So one must keep out of the way of them!

ALEXANDRA (to Mariamne).

Then I shall go and try to tell my friends

Somehow by signs how matters stand with us.

MARIAMNE. By signs-your friends-oh mother, mother! So

It really is yourself and not the people?

I hope you are not digging your own grave!

(Alexandra starts to go)

JOSEPH. With your permission I shall send along

My man-at-arms. Philo!

ALEXANDRA.

Open war then?

(Philo enters; Joseph speaks to him in low tones, then aloud)

JoSEPH. You understand?

FHILO.

Yes!

JOSEPH.

As a last resort!

PHILO. I am to watch, and thenJOSEPH.

Your head is pawn!

(aside) It seems that Herod's spirit is within me!

Alexandra (aside). But yet I go! Perhaps this man-at-arms,

Although a Galilean, may be won!

I can but try! (exit; Philo follows her)

Joseph (aside). There is no other way

However much it throws suspicion cn me,

For the revolt drives me to take this step,

I do not dare lose sight of her, unless

I want to make the deed impossible;

His messenger may come at any hour!

1260

I gave up long ago expecting Herod.

Mariamne. And when did Herod die?

JOSEPH.

When did he die?

MaRIamne. And how? You ought to know, you risk so much!

JOSEPH. What am I risking then? You ask a riddle! 
MARIAMNE. Nothing, if you believe I shall not find

Protection when the Romans hear my life

Is threatened, everything if you are wrong.

JOSEPH. And who is threatening your life?

MARIAMNE.

You ask?

You!

JOSEPH. I?

MARIAMNE. And can you swear the opposite?

By your child's head! Well, can you?-You are silent!

1280

JoSEPH. You have no right to ask an oath of me.

MARIAMNE. One so accused denies it of himself.

Alas for you if Herod now returns!

Two things I have to say before I kiss him,

The one is, that you planned to murder me,

The other, what I swore; now judge yourself

What fate is waiting for you when he comes!

JoSEPH. What did you swear? If it shall frighten me,

Then I must know it.

MARIAMNE.

Let it be your curse!

That I will kill myself with my own hand

If he-Ah! Now you think: Had I but known that!

Why then I should have paid no heed at all

To a cold greeting, should have gone ahead

As I began and now all would be well!-

You were a very different man at first!

1285

JOSEPH. I have no thing to fear!

Mariamne. Because you think

It is impossible that he return!

Who knows! And if! Then I shall keep my oath.

But not until $I$ am avenged on you,

Till I have so avenged myselif-yes, tremble-

1300

As he would have avenged me! Draw your sword

At once! Draw it! You dare not? I believe it!

However you may guard me, I shall find

A way to Captain Titus I am sure!

Your game is lost, since I have found it out.

1305

Joseph (aside). True!

(to Mariamne) I shall hold you to your word! You will

Avenge yourself as Herod would avenge you!

You have vowed that to me! Do not forget it!

Mariamne. Thus madness speaks! That Herod loves me

Far more than I can love myself, no one

Will doubt, Salome even will not doubt it,

That tricky wife of yours, not even if

She hate me doubly for it, even if

She be the one who for revenge has put

The ugly thought of murder in your head!

That the idea comes from her, I know, 
And I will smite her so it hurts, her grief

For you shall be my last real joy on earth!

JUSEPH. Though wrong, it matters not! I have your word!

Mariamne. You keep repeating it? Accursed man,

What fearful turmoil of dark thoughts you wake

In me, and what suspicions in my breast!

You speak as if King Herod had himself

Picked you as sacrificial priest and me

As victim. Is it so? As he took leave

He dropped a vague dark hint, I think of it

With horror. Answer!

JOSEPH.

I shall answer you

As soon as necessary, when I know

That he-

MARIAMNE. No longer can expose your lies,

When you with evil cowardice accuse him

Of the most terrible and monstrous thing

Only to clear yourself from my suspicions?

I tell you, I will hear you only now,

When he, perhaps before you even finish,

May enter at the door and strike you down!

1335

Keep silent then forever, or speak now!

JoSEPH. And if it were? I do not say it is!

But if it were? What else then would it be

Than confirmation of the things you feel,

Than proof that he loves you, as no man yet

Has ever loved his wife?

MARIAMNE.

What did you say?

It seems to me I heard that once before!

JOSEPH. I thought that it would only flatter you

If death were not one half as bitter for him

As is the thought of leaving-

1345

MaRIAMNe.

What the wager,

That I myself can finish that for you!

As is the thought of leaving me behind

Within a world where Antony still lives!

JOSEPH. Well, yes! I do not say that he said that-

MARIAMNE. He said it! He said-Oh, what did he not say!

If he would only come!

JOSEPH.

But Mariamne!-

(aside) I have become entangled! Yet I did

No more than what I had to! But I fear

That he-I see the dead Aristobulus.

Accursed be the deed that throws a shadow

Before it's even done!

MARIAMNE.

So it was more

Than merely empty bubbles in my brain,

As may sometimes develop and then burst, 
It was-My life is only now beginning, Until today I dreamed!

\section{SCENE 6}

\section{A servant enters, Saiome follows.}

SAlome (to the servant). Were you commanded

To let no person enter unannounced?

I take the blame!

JOSEPH.

SALOME.

Salome, you?

No evil spirit, only your poor wife,

Whom you once wooed as Jacob wooed his Rachel

And whom you now-(to Mariamne) Accursed woman, was

It not enough to turn my brother's heart

Away from me? Do you now have to steal

My husband from me too? Both day and night

He thinks of you, as if you were a widow,

And I still less than that! By day he dogs

Your footsteps everywhere! By night he dreams

Of you, and anxiously calls out your name,

He starts up out of sleep-(to Joseph) Did I not charge you

With that this very morning? Even today

When all Jerusalem is in revolt,

Today he's not with me, nor in the market

Where I had sent because he did not come,

$\mathrm{He}$ is with you, and you-you are alone!

MARIAMNE. It surely, is not she. So it is he!

If any doubt were still remaining, then

This silly jealousy has stifled it!-

For him I was a thing and nothing more!

JOSEPH (to Salome).

I swear-

SALOME. That I am blind? Oh no! I see!

MARIAMNE. The dying man who would cut down his fig tree

Because he could not bear to have another

Enjoy its fruit when he himself was dead,

He would be culpable, and yet perhaps

He had set out the tree himself and knew

That it would give refreshment to the thief

Or even to the murderer who shook it.

In my case that's not so! And yet! And yet!

That is a crime whose like there never was.

SALOME (still speaking to Joseph).

You speak in vain! Commission! What commission?

Mariamne. Commission! That the seal!-If it could be,

Then now's the time it would be possible!

1385

But it's not possible! However great 
The turmoil in my breast, my soul is still

Unsullied by a single base emotion!

This moment I would give to Antony

The selfsame answer that I would have given

1400

Him on our wedding day, I feel that, so it

Affects me as it does. Were that not so,

Then I would have to bear it, yes, forgive it!

SAlome (to Mariamne).

You do not seem to see me here!

Mariamne.

I do!

And what is more, you have done me a favor,

The greatest favor, I was blind and now

I see, see clearly, and alone through you!

SALOME. You scoff at me? You shall do penance for it,

If only Herod will return! I will

Tell everything to himMARIAMNE.

What? Oh yes! Do that!

If he gives ear - - Why not? Why do I laugh?

Is that impossible? - - And if he listens,

You have my word, I will not contradict you!

I do not love myself enough for that!

\section{SCENE 7}

AleXANDRA (rushes in). The King!

JOSEPH.

ALEXANDRA.
In town? 


\section{ACT III \\ Castle Zion. Alexandra's rooms.}

\section{SCENE 1}

Alexandra. Joseph. Salome.

Herod enters with his retinue. Soemus.

Herod. Well, here I am! (to Soemus) Is it still bleeding? The stone

Was meant for me, and you were only struck

Because you came just then to tell me something.

And so this time your head was your king's shield!

If you had only stayed back where you were-

Soemus. I would not have the wound, nor credit either,

If credit be deserved. In Galilee

That man at most is stoned who dares oppose

Both you and me, for I am but your shadow,

Or better still your mouthpiece or whatever

1425

You will.

HEROD. Yes they are very loyal there,

At least to their own interests, and to mine

Because their own go hand in hand with mine.

Sosmus. How much they do is shown you by the fact

That you have found me in your capital.

HEROD. In fact, I was surprised to find you here;

For when the king is gone, there is more need

Of watchers in the restive provinces!

What was it then that drove you from your post?

It certainly can not have been the wish

To prove to me it was not dangerous

To leave it, nor was it the premonition

That there would be a stone to intercept!

Soemus. I came to town in all due haste to see

The Viceroy and disclose direct to him

A few peculiar facts I have discovered.

I wanted to report to him, that even

In Galilee the Pharisees are trying,

Without success, to undermine the ground;

And yet my warning came too late, I found

Jerusalem in flames and I could only

Help him to put them out!

HEROD (shakes hands with him). And that you did

With your own blood!-Ah, Joseph, greetings to you!

I thought to find you elsewhere!-Never mind!

But go at once and bring me Sameas,

The Pharisee, whom the Roman Captain Titus

Is holding captive as the Scythians do.

The stubborn Roman has been hauling him 
Around with him behind the horse he rides, Tied to its tail; in his fanatic zeal

He spit at him upon the open square.

And so he has to run, as he perhaps

Has never run before, to keep from falling

And being dragged along. I should at once

Have turned him loose as I was riding by!

My thanks are surely due to him alone

That now I know who all the serpents are

Who hitherto have crawled away unseen!

I now can crush them easily at will! (exit Joseph)

Herod (to Alexandra). I greet you too! And from Mark Antony 1465

I bring a message to you that you can

Not hale a river into court, much less

A king within whose land the river flows,

Because he did not fill it up with earth!

(to Soemus) I would have been here long ago, but friends

1470

Who do not often see each other, find it hard

To bring themselves to part! And it will be

That way with us, I tell you in advance,

Now that I have you here again at last.

You must be here to help me feast on figs

As I helped Antony consume the morays,

Delicious smothered in Falernian wine,

A gourmand's dish! He had me tell him tales

About our younger days just to refresh

His memory! So you must be prepared

To do the same for me. Though I have not

So much of the triumphant victor in me,

That I would ever summon you to me

As he had summoned me to him, pretending

That he believed such an absurd complaint,

With knitted brows like Caesar, armed as well

With lightning and with thunderbolt

To make quite sure that I should really come-

That was the only reason why he did it-

Yet I shall take advantage of the chance

Which brings you to Jerusalem today

And say, as he, when you begin to talk

About your duty: If you do it, as

You should, it will not need you every moment!

You come so rarely that it seems you do

Not like to come!

Soemus.

You do me wrong, and yet

I have good reason not to come too often!

HERod (to Salome). Are you here too? So have you learned at last, When you meet Mariamne, to imagine

That you are only looking in a mirror 
And what you see there is your own reflection?

I often gave that good advice to you

When you were piqued at her,-you never took it!

Now do not take the joke amiss and spoil

The joy of our reunion! But, where is she?

1505

They told me I would find her with her mother,

So I came here!

SALOME.

She went when she was told

That you were coming!

HEROD.

Went? Impossible?

And yet, perhaps! Since it would be more fitting

To meet alone!-(aside) Do you feal anger, heart,

Instead of asking pardon?-She is right,

I'll follow her!

SALOME. That's right, deceive yourself,

Explain her fear at seeing you alive,

Her shame for having thought you dead, and more

Because she knows she is no. longer widow,

1515

Explain it all as but a maiden's shyness,

A maiden who has never known a man,

Not the confusion of a sinful woman!

She left because of fear!-

HEROD.

Of fear?-Look round you,

We are not here alone!

SALOME.

That suits me well,

1520

If $I$ accuse when witnesses are present,

Then my complaint will be more surely heard,

And will be harder to suppress!

HEROD.

You place

Yourself between my wife and me? Take care,

You might be crushed!

SALOME. This time I shall not be,

1525

Although I know how much a sister counts

With you, when it involves this Maccabee,

This time-

HEROD. I have one thing to say! The day

On which I saw her first, if on that day

Someone had entered a complaint against her

He would not easily have found a hearing,

But easier still than now! Be warned by that!

I owe so much to her that she can not

Owe anything to me! I feel it deeply!

SALOME. She has full freedom then?

HEROD.

To wear what mask

She will to aid her in deceiving you,

If she finds joy in making sport of you.

SALOME. Then-then I must keep still. Words would be vain!

Whatever I might say to you, you always 
Would have your answer ready: Mummery!

This mummery has had a fair success,

It fooled not me alone, it has deceived

The world as well and it costs you your honor

And me my peace of mind, though you may swear

That Joseph only did what was his duty

1545

When he-but see if any man believes you!

HEROD. When he-what is it you withhold? Go on!

But no - not yet! (to a servant) A message for the Queen.

I ask her presence here!-Does it not seem

As if the whole wide world were free of spiders

1550

And all of them were nesting in my house,

And when for once the blue of heaven seems

To shine for me they start to spin their webs

And hide it as with clouds? In fact-it's strange

She does not come. She really should have kissed me,

1555

Succumbing to the impulse of the moment,

And then have bit her lips in her distress

If after all the ghost had not yet gone!

(to Salome)

You know what you have ventured? Woman, you know?

I was so happy! Understand? And now-

The earth once spilled a glass of wine for me

When I was thirsty, for it started quaking

When I had not yet finished drinking it;

That I forgave because I had to. But now-

On you I could take vengeance!

\section{SCENE 2}

\section{Mariamne enters.}

HEROD.

Cast yourself

1565

Down at the feet of her you openly

Insulted, then I will not!

SALOME.

AlEXANDRA (aside).

HEROD. Well, Mariamne?

MARIAMNE.

I have been summoned and I have appeared.

Alexandra (aside). Is this the wife who swore to kill herself,

If he did not return?

HEROD.

Is this your greeting?

MARIAMNE. The King has sent for me to give him greeting,

I give him greeting! Thus the task is done!

ALEXANDRA. How wrong! You stand arraigned before a court.

HEROD. There was a charge about to be preferred

Against you! So I sent for you to come

Before I heard it, but it truly was not 
So that you might defend yourself against it,

Only because I think it will be stifled

Quite of itself if you are present here!

1580

MARIAMNE. To hinder that I ought to go again!

HERoD. But Mariamne? Never were you one

Of those so wretched pitiable souls

Who, even as they see the face or back

Of foe, forgive and are once more disgruntled

1585

Because they are too weak for honest hate,

Too small to be completely generous.

What then has so transformed your very soul

That now you seem to be as one of them?

Before I left, you gave me a farewell.

1590

This led me to expect a welcome from you,

Do you refuse me that? You stand there now

As if the hills and plains that lay so long

Between us still were separating us?

And you step back when I come closer to you?

1595

Is my return so hateful to you then?

Mariamne. Why should it be? It gives me back my life!

HEROD. Gives back your life! Ah! What a word that is!

Mariamne. But you will not deny you understand me!

HEROD (aside).

Can she then know it? (to Mariamne) Come!

(since Mariamne makes no move) Leave us alone! 1600

(to Alexandra) Pardon!

ALEXANDRA.

Of course!

MARIAMNE.

(exit; all the others follow her)

HEROD.

The coward!

MIARIAMNE.

Coward?

What shall I call it?

HEROD.

And?-(aside) That would be dreadful!

For never could I blot it out in her!

MARIAMNE. Whether his wife shall follow him in death

By her own choice, or hangman strike her down-

1605

It matters not if she but dies! He leaves

No time for her to sacrifice herself!

HEROD. She knows!

MARIAMNE. Is Antony a man, as I

Believed till now, a man like you, or is he

A daemon as you must believe, since you

1610

Do seem to doubt there is a sense of duty

Or remnant of a pride within my bosom

That would resist, if dripping with your blood

He came as suitor for my hand and urged me

To help him while away such leisure time

As the Egyptian may perchance leave free? 
HEROD (aside).

But how? But how?

MARIAMNE.

He would of course have had to

Put you to death before he could woo me,

And if you feel yourself so valueless,

I never would have thought it but I see it,

That you are fearful, lest the very fullness

Of manly worth in you would not outweigh him

In your wife's heart, yet by what right do you

Believe I am so low, that you should fear

That I would not repulse the murderer?

1625

Oh double shame!

HEROD (breaking out). What was the price you paid

To get this secret? For it was not cheap!

A head was my security!

MARIAMNE.

Salome,

How well you knew your brother!-Ask the man

From whom I learned of it what he received,

No further answer will you get from me! (turns away)

HEROD. I'll show you now just how I question him!

Soemus!

\section{SCENE 3}

Soemus enters.

HeRod. Is my brother Joseph there?

SoEmus. He waits with Sameas.

HiEROD.

Take him away!

I gave a note to him. Tell him he shall

Deliver it at once! Accompany him

And see that everything that it commands

Is faithfully performed!

SOEMUS.

It shall be done! (exit)

HEROD. Whatever you suspect, or think, or know,

You still misjudge me!

MARIAMNE.

On my brother's murder

1640

You put the seal of real necessity

And one must bow to that, however much

One shudders, but you never will succeed

In stamping any plan to murder me

With this same seal, it will remain just what

It is, a crime one can at most repeat

But neither now nor ever can surpass!

HeroD. I would not have the courage to reply

If I, however much I might have risked,

Had not been sure of what the end would be.

But sure I was, and I was only sure

Because I staked my all upon the play!

I did that which the soldier well may do 
In battle sometimes as a last resort,

He hurls the standard from him which he carries,

1655

Upon which fortune, honor, both depend,

Right in the midst of milling foe he hurls it,

But not because he thinks to let it go:

He plunges after it, he brings it back

And brings the laurel too, though sadly torn,

1660

The wreath of victory which even ccurage

No longer could attain but only desperation.

You called me coward. If a man is that

Who feels a demon in himself and fears it,

Then sometimes I am cowardly, but only

When I must reach my goal by devious paths,

When circumstances force me to pretend

That I am not the man I really am.

Then I am fearful I might show myself

Too soon, and so to tame my pride,

Which easily aroused might spur me on,

I fix on something which is more than I,

On something which must stand or fall with me.

You know what stood before me when I left?

No duel and still less a court of justice,

But a capricious tyrant, in whose presence

I was supposed to hold myself in check

But surely would not if-I thought of you,

And did not even grind my teeth-however

He might offend the man and king in me

While dragging me from feast to feast, and yet

So strangely silent, putting off the pardon;

As patient as a slave I bore it all!

MARIAMNE. You speak in vain! In me you have offended

Humanity; all who like me are human

Must share my pain. One need not be my kin,

One does not need to be like me a woman.

When you by secret underhanded murder

Did rob me of my brother, only those

With brothers could weep with me. All the others

Could stand aloof, refusing sympathy,

Dry-eyed. But everyone who breathes has life,

And no one willingly lets life be taken

From him save by the hand of God alone,

Who gave it to him! Such a monstrous crime

The whole wide human race condemns and hates,

The fates condemn, who, though they let it start,

Can not permit completion, you yourself condemn it!

And if you have so deeply hurt what's human

In me, then tell me, how is the wife to feel,

How do I stand with you and you with me? 


\section{SCENE 4}

Salome rushes in.

SALOME. What awful deed have you in mind? I see

My husband led away-and he implores me

To plead with you for mercy-I hesitate,

For I am angry, do not understand him-

1705

And now-now fearful whispers reach my ears,

They say-Their words are lies?

HEROD.

Your husband dies!

SALOME. Before he has been judged? It cannot be!

HeroD. He has been judged and by himself! He had

The document condemning him to death

1710

In his own hands before he sinned against me,

He knew the punishment awaiting him

If he should do it; he accepted it

And yet he did it!

SALOME.

Herod, listen to me!

Are you so sure of that? Oh I complained

1715

Against him, I believed that I was justified,

I had good reason for it-that he loved her

Was obvious, no longer did he have

A glance for me, or pressure of the hand-

He was with her by day whenever possible,

And in the night his dreams betrayed to me

How much his mind was with her-That is all

Quite true, and more-And yet it does not follow

From this, that she must love him in return,

Still less, I grant, that she-Oh no! oh no!

1725

My jealousy had carried me too far-

Forgive! You too forgive. (to Mariamne) I hated you!

Oh God, how fast time flies! They said-Am I

To love you, as I hated you? Then be

No longer silent, say that he is guiltless,

1730

Beg mercy for him, just as I myself!

Mariamne. He is!

HEROD.

In her sense, yes-but not in mine!

MARIAMNE. In your sense too!

HEROD.

But then you would not know

The thing you know! Now nothing can excuse him!

And if I have him put to death and do

Not first give him a hearing, then one reason

I do is this: because I want to show you

I think no ill of you and deeply rue

The hasty word I spoke at first in anger,

But more because I know that he has nothing

He can say to me! 


\section{SCENE 5}

SoEmus (enters). The bloody work

Is done! But all Jerusalem's astounded

And asks just why the very man whom you

Selected to be Viceroy in your absence,

When you left here for Egypt, had to lose

1745

His head at once when you return!

SALOME (totters).

Alas!

(Mariamne starts to catch her)

Away! Away! (to Herod) And she? HEROD.

Believe me, sister!

Your husband has deceived me terribly-

SALOME. And she?

HEROD.

Not in the way you think-

SALOME. Then how?

You want to save your wife. But if my husband

So terribly deceived you, she did toc,

For what I said is true, and everyone

Shall know of it who does not know it yet!

You must now wash in her blood, as in his,

Else you will ne'er be clean again! You must!

Herod. By all that is most sacred to me-

SALOME.

Name

His crime to me, if that is not the one!

HenoD. Were I to name it, I should make it greater!

There was a secret I entrusted to him,

To me it was important, he betrayed

This secret, and shall I betray it too?

Salome. Wretched excuse, supposed to frighten me!

You think you can deceive me? You believe

In everything I told you, but you are

Too weak to stifle and suppress your love,

And you prefer to cover the disgrace

You are unwilling to wipe out. Unless

You kill me too, your sister, as you did

My husband, you will not succeed!

(to Mariamne) He's dead,

Now you can swear whate'er you will, he will

Not contradict you! (exit)

HEROD.

Follow her, Soemus,

And try to calm and soothe her! You know her,

There was a time when she would listen to you!

Sozmus. Those times are long since past! But still I go! (exit)

MARIAMNE (aside). I would not ask for mercy for the man

Who sought to murder me! And yet I shudder-

There was not even time enough to do it! 
HEROD (aside). It simply had to be. He could have had

Uriah's place assigned to him in battle!

But now I grant that I regret my haste!

\section{SCENE 6}

Messenger (enters). I come from Antony!

HEROD. I know then too

What word you bring. I must at once make ready.

The battle is at hand of which he spoke!

MiEssenger. Octavius already has embarked

For Africa, and Antony has joined

1785

With Cleopatra and set out with haste

To clash with him at once near Actium-

HEROD. And then I, Herod, am to be the third!

Good! I shall go today! Soemus can

Replace me here although affairs are bad.

1790

It's well he came!

MARIAMNE.

He has to go again!

I thank Thee, God!

HEROD (watching her). Ha!

MIESSENGER. No, great King, no!

His need is not at Actium, he wants

The Arabs, who have risen in revolt,

Held down and not allowed to join the foe!

1795

That is the service he requires of you.

HEROD. It is his place to name the spot to me

Where I can be of use!

MARIAMNE.

Once more! That gives him

Another chance!

HEROD (as before). See how my wife rejoices!

$$
\text { (to the messenger) }
$$

Tell him-but you already know!-(aside) Her brow

Is smooth, her hands are folded as in prayer-

Such is her heart!

MísSENGER.

But is there nothing else?

MARIAMNE. Now I shall see: was it a fever only,

The fever of a passion so aroused

That it confused him, or his inner self

Which thus betrayed itself to me so clearly?

Now I shall see!

HEROD (to the messenger). There's nothing more! (exit messenger)

$$
\text { (to Mariamne) Your face }
$$

Now looks more cheerful! But you must not hope

Too much! One does not always die in war,

I have returned from war before, so often!

MARIAMNE (starts to speak but restrains herself).

No! No! 
HEROD. The battle this time is more fierce

Than e'er before. All other times the struggle

Was fought for something in the world, but now

It's for the world itself. It shall decide

Who rules the world, is it Mark Antony,

1815

The profligate and libertine, or is it

Octavius, whose sole claim to merit is

That never in his life has he been drunk.

Great blows will be delivered and received,

Yet it is possible your wish will not

1820

Be realized, that death may pass me by.

Mariamne. My wish! Of course! My wish! It's well this way!

Be firm, my heart, do not betray yourself!

The test is none if he suspects what moves you!

And if he proves his worth, how great is your

Reward, how great his too can be! Then let him

Misjudge you! Test him! Keep the end in mind!

Think of the crown which you can hand to him

When he has overcome the demon in him!

HEROD. I thank you! You have now relieved my heart!

Although quite possibly I have transgressed

Against humanity in you, yet this

Is clear, I have not sinned against your love!

So I no longer beg you by that love

To make a final sacrifice, however,

I hope that you fulfill one final duty.

I hope for that not merely for myself,

For your own sake I hope for it much more.

You will not want me after this to see

You only in a fog; since I have sealed

The dead man's lips I hope you open yours,

And in his place explain to me, just how

It came that he presented you his head;

Because of your humanity you will,

Because of your own self-respect you will!

MARIAMNE. To keep my self-respect, I will not do it!

HERod. So you refuse me what is reasonable?

MARIAMNE. Is reasonable! You think it would be that

For me to fall upon my knees before you

And swear: Your servant, Sire, did not come near me!

And so you can believe,-I have no right

To confidence although I am your wife-

Hear this besides, and this! Oh shame! Oh shame!

No, Herod, no! If curiosity

Should sometime ask, perhaps! Now I am silent!

HEROD. Yet if your love had been but great enough

To pardon all that I have done for love,

I never would have asked the question of you! 
But since I know how small it is, I must

Repeat the question now, for such assurance

As is afforded by your love can only

Be as great as is your love itself,

And any love that values life more highly

Than the beloved, seems to me quite worthless!

MARIAMNE. And I am silent still!

HEROD.

Then I declare

1865

I will not kiss the lips again that are

Too proud to swear no other man has kissed them,

Until they do it in humility;

Yes, if there were a means of wiping cut

All memory of you within my heart,

1870

If I by simply piercing both my eyes,

Effacing thus the mirror of your beauty,

Could by that means efface your image too,

Then I would pierce them in this very hour.

MARIAMNE. Herod control yourself! I think perhaps

1875

Right now you hold your fate within your hands,

Mayhap can even turn it as you will!

For every man at some time comes the moment

In which the guider of his star gives him

The reins to hold, and only this is bad,

He can not know the moment and it may

Be any that comes rolling by! I feel

So sure this very one is yours! So stop!

As you tociay mark out your course of life

You well may have to walk it to the end:

Will you do that in the wild flush of anger?

HEROD. I am afraid you sense but half the truth,

The turning point is here but is for you!

For I, what do I want? Only a means

With which to frighten evil dreams away!

MARIAMNE. I do not want to understand! I bore

You children! Think of them!

HEROD.

One who is silent,

As you are, wakes suspicion that he fears

To tell the truth but does not want to lie.

MARIAMNE. No further!

HEROD.

Good, no further! So farewell!

And then when I return, let that not rouse

Your anger too much!

MARIAMNE.

Herod!

HEROD.

Be quite sure

I will not try again as now to force

A greeting from you!

MARIAMNE.

There will be no need

Of that again! (to Heaven) Guide Thou his heart, Oh God! 
I had forgiven him my brother's murder, I was prepared to follow him in death, I still am, can a mortal then do more? God, Thou hast done what Thou hast never done, Rolled back the wheel of time, things stand again 1905 Just as before, oh let his actions this time $\mathrm{Be}$ different, then I will forget the past, Forget it as I would if he had made

A thrust at me in fever with his sword And then, recovered, bound my wound himself.

(to Herod) Shall I see you again? HEROD. If you should see me,

Then call for chains! For that will prove to you

That I have gone insane! MARIAMNE.

You will regret

This word!-Restrain yourself, oh heart!-You will! (exit) HEROD. It's true, I went too far. Already I

Have said that to myself. But no less true,

That if she loved me she would pardon it!

Yes, if she.loved me! Did she ever love me?

I think she did. But now-Her brother is

Revenged, though he is dead and in the grave!

1910

I had him killed to make my crown secure.

He took with him what matters more: her heart!

For since her brother died, her attitude

Toward me is strangely changed. When I compared

Her with her mother, never did I find

The slightest trace of similarity,

Today she seemed in more than one way like her;

No longer can I trust her as I did!

That is quite sure! But is it necessary

That I assume at once she has deceived me?

The guarantee I had because she loved me,

That now is gone, a second guarantee

I still have in her pride, and will a pride

Which scornfully disdains all self-defense

Not scorn still more thus to besmirch itself?

It's true, she knows it! Joseph! Oh! Why can

Man kill and not awake the dead again?

He should be able to do both or neither!

$\mathrm{He}$ is revenged! He is not here! And yet

I see him! "You command?"-It can not be!

No! I will not believe it! You, Salome,

Silence! Howe'er it came, it was not thus!

Perhaps the secret, like a fire inside him, Ate through him by itself. Or he betrayed it, Because he thought me lost and now he wanted To reconcile himself with Alexandra 
Before the news arrived here. We shall see! For I must test her! If I had but dreamed She ever could find out, I never would Have gone so far. But since she knows it now, 1950 I must go further! For because she knows it, I now must fear from her revenge those things Which I had feared from her inconstancy, Perhaps quite wrongly. I must fear that she Will celebrate a wedding on my grave!

Soemus came quite opportunely. $\mathrm{He}$ is

One who would stand where I now stand, were I

Not in the world. His very coming proves

How loyally and zealously he serves me.

I will give him the order now! I know

She will lure nothing out of him, if she

Tempts him by human means!-If he betrays me, She will have paid a price, which is-Salome

Then you were right!-The test will give the answer! (exit) 


\section{ACT IV \\ Zion Castle. Mariamne's rooms.}

\section{SCENE 1}

Mariamne and Alexandra.

AlEXandra. Your words and acts are riddles. First your oath: 1965

If he does not return, I too shall die!

Then bitter coldness when he came, defiance

Which could not but arouse his anger, as it

Gladdened me! Now again the deepest mourning!

Is there a person who can understand you?

MARIAMNE. If you find that so hard, why vex yourself?

Alexandra. And then the harsh and yet reluctant way

In which you keep Soemus at a distance!

One sees that he has something on his mind-

MARIAMNE. You think so?

AleXANDRA.

Yes! And he would like to tell us,

Only he does not dare, he would perhaps

Be doubtful, if he saw you throw yourself

Into the Jordan, whether he should try

To rescue you from death; he would be right,

For you have treated him disdainfully!

Mariamne. That is quite true, and Herod can not say,

That I have tempted his good friend, that I

Have lured his secret from him, if he has one,

By cunning flattery. It's in the hands

Of Heaven, whether I shall ever learn it!

I feel it in my heart, I'm risking nothing!

\section{SCENE 2}

Sameas (enters, his hands in chains).

The Lord is great!

MARIAMNE.

AlexANDRA.

In chains? Another riddle!

SAMEAS.

$\mathrm{He}$ is!

You free and yet

Remove these chains again! Jerusalem

Shall be reminded by them day by day

That Jonah's grandson had to sit in prison.

Alexandra. How then did you escape? You bribed the guards? Sameas. I bribed? The guards?

ALEXANDRA.

Of course and yet with what?

You still have on your woven gown of hair,

I doubt if they would let you out if you

Had told them where to find a nest of bees,

As you well could who know just where to find 
Each hollow tree, for honey is not scarce!

Sameas. Why do you ask? Soemus opened up

The gates for me himself!

2000

Mariamne.

Would he have dared?

SAMEAS. Why not? I thought that you had ordered it.

MARIAMNE. I?

SAMEAS. No? And yet it seems to me he said so!

I can be wrong, for I was just repeating

The last Psalm backwards when he came, and so

I listened to him with but half an ear!

2005

Oh well! So then it was the Lord, ard I

Must go up to the Temple to give thanks

And have no errand here in David's palace!

MARIAMNE. The Lord!

SAMEAS.

The Lord! Was I then justly jailed?

Mariamne. Those times are long since past in which the Lord

Was wont to speak directly to his people.

We have the law instead, and it speaks for Him!

The pillar of fire and smoke has ceased to be,

By which he marked the paths across the deserts

For our forefathers, and the prophets are

2015

As silent as the Lord!

Alexandra.

Not all are silent!

Just recently one prophesied a fire;

This prophecy was afterward fulfilled!

MARIAMNE. Of course, but he himself had set the fire

At midnight.

SAMEAS.

Woman! That is blasphemy!

2020

MARIAMne. It is no blasphemy, I know it happened!

$\mathrm{He}$ is a Pharisee as you yourself,

He speaks like you, he raves like you, the fire

Was planned to be the proof he really was

A prophet able to foresee the future,

2025

But then a soldier caught him in the act.

SAMEAS. A Roman?

MARIAMNE.

Yes!

SAMEAS. He lied! He was perhaps

A hireling! Had perhaps been hired by Herod

Or hired by you!

MARIAMNE.

Do not forget yourself!

Sameas. You are his wife, the wife of the blasphemer

Who looks upon himself as the Messiah;

Since you can clasp him in your arms and kiss him,

You might do other things for him as well!

Alexandra. He looks upon himself as the Messiah?

SAMEAS. He does, he told it to me to my face

When he was having me led off to prison.

I cried unto the Lord, I cried: Oh guard 
Thy people, send us the Messiah whom

Thou promised us in times of direst need,

Those times are now upon us! Then he said

2040

With haughty scorn: Oh He is long since here,

You merely do not know it! I am He!

AlexandRa. Well, Mariamne?

SAMEAS. With accursed wit

He proved we are a folk of lunatics

And he alone enjoys the gift of reason,

2045

We do not dwell in vain beside the Dead Sea,

In which there is no ebb and flow of tide,

And that explains why everyone is tainted.

It is a faithful mirror of ourselves!

But he intends to give us life and vigor,

2050

Even if he must take that stupid book

Of Moses from us-such his impious words-

For that bears all the blame that we are not

More like the Jordan, our clear river, rippling

Along so merrily, but like a swamp.

2055

Alexandra. He threw away his mask completely?

SAMEAS.

Yes!

Perhaps, however, when he did, already

He thought of me as dead; right afterward

$\mathrm{He}$ ordered that I die.

MARIAMNE.

He was provoked!

He found rebellion here!

SAMEAS.

I now remind you

2060

Of what your duty is. You must rerounce him

Even as he renounced the Lord! You can

Thus punish him, for Herod loves you much!

And when Soemus set me free I thought

You had already done it. Unless you do it,

Then do not call the lightning from the clouds

At all unjust, if it strikes you like him!

I go to offer sacrifice!

Alexandra.

Then take

The victim from my flock!

SAMEAS.

I take it where

It's missed! The widow's lamb, the poor man's sheep!

What use has God for yours! (exit)

\section{SCENE 3}

SOEMUS (comes).

Your pardon!

MARIAMNe.

About to summon you! I bid you welcome!

Soemus. This is the first time, is it not?

MARIAMNE.

It is! 
Sozmus. You have avoided me till now!

MARIAMNE. Have you

Sought me and have you something then to seek?

2075

I do not like to think of it.

SoEmus.

One thing at least:

Consider me as your most faithful servant!

MARIAMNE. I did, but I no longer do!

SOEMUS.

No longer?

MARIAMNe. How can you open up the prison doors

And let the rebel out whom Herod jailed?

2080

Is Herod still the King, or is he not?

Soemus. The answer's not as easy as you think!

MARIAMNE. If it is hard, then you will have to suffer!

Sozmus. You have not heard the battle has been lost!

MARIAMNE. At Actium? The battle has been lost?

2085

Sozmus. Mark Antony has died by his own hand!

Queen Cleopatra too, by hers!

MARIAMNE.

She had

The courage? She could never bear to look

Upon a sword, recoiled from his when once

He held it up before her as a mirror!

2090

Soemus. It was reported so to Captain Titus!

Octavius cursed aloud because they were

Not hindered! I myself read the dispatch!

Mariamne. Then Death has had his share for many days

And every head is safer than it was

Before!

SoEmus. Do you think so?

Mariamne. You smile so strangely!

SoEmus. It seems you do not know Octavius!

He will not ask if Death is surfeited,

He will prepare another feast for him

Of friends of Antony, there is no lack

2100

Of dainty morsels for this feast of death!

Mariamne. Does that apply to Herod?

SOEMUS.

If he does

What he proposed-

Miariamine.

And what was that?

SOEMUS

He said:

My love for Antony is past, I would

Much rather say I hate him, but I shall

2105

Continue to stand by him till the last,

Although I am afraid that he must fall,

I owe it to myself, if not to him!

Mariamne. Quite like a king!

Sozmus. Yes, like a king! Only

Octavius is not one to admire it,

If Herod should do that- 
MaRiame.

Who dares to doubt?

SoEmus. Then he is lost indeed, or else they wronged

Octavius grieviously when they held him

Responsible for all the bloody slaughter

That followed Caesar's death!

That you believe

So firmly in this outcome, that already

You number Herod with the dead, is clear,

Or else you would not dare what you have dared.

I shudder too, and I admit it freely,

At your assurance, for you are no fool,

2120

And surely not without good reason risk

So much. And yet, however things may stand,

I still am here and I assure you, that I

Will find a way to bring obedience

To him in death, not even one command

2125

That he has given shall be unfulfilled,

And that shall be his sacrifice!

SoEmus.

Not one!

I doubt it, Queen!-(to himself) Now let the blow descend!

MARIAMNE. As surely as I am a Maccabee,

You shall send Sameas back to his prison!

Soemus. If you desire it, then it shall be done,

If you want more, if he shall die, just as

The King decreed, speak and he is dead!

But now may I have leave to ask a question:

Am I, so that the sacrifice you plan

To offer for the dead may be complete,

Am I to take my sword and thrust it through you?

That too is a command he left with me!

MARIAMNE. Alas!

ALEXANDRa. Oh no!

MARIAMNE. So then the end is here!

And what an end! So dwarfing the beginning

And everything besides! The past, the future

As well, for me it all dissolves to nothing.

I had nothing, I have nothing, I shall

Have nothing. No one ever was so poor!

ALEXANDRA. Whatever evil deeds you might report

Of Herod, I could well believe them all,

But this-

Mariamne. Oh do not doubt! For it is true!

ALEXANDRA. Do you say that?

MARIAMNE. Oh God, I know well why!

ALExandra. Then you will know what you must do!

MARIAMNE.

(she aims the dagger at herself)

ALeXaNdRa (preventing her). 
Have you gone mad? Is that what he deserves?

That you should act the hangman on yourself?

Mariamne. That was reversing it! Thank you! He chose

This office for himself!

(she hurls the dagger from her)

Away, you tempter!

ALEXANDRA. You will now seek protection of the Romans!

MARIAMNE. I shall not hinder anyone for whom

That seems important-I myself tonight

Will give a feast!

Alexandra.

A feast!

MARIAMNE.

There I will dance! -

Yes, yes, that is the way!

AlexandRa.

And to what end?

MARIAMNE. Ho, servants! (servants come)

Open up the banquet halls!

Invite all those who feel in festive mood!

Light all the candles, any that will burn,

Pluck all the flowers that are not yet wilted!

There is no need of leaving any over!

(to Moses) You once arranged the wedding feast for us,

This feast today must far surpass that other,

So spare no effort! (she steps forward) Herod, tremble now!

And even if you never did before!

Sogmus (steps up to her).

I feel the pain as much as you!

Mariamne.

I do

Not want your pity! You are not a hangman,

I have no call to doubt, for you have shown it;

2170

Instead you are a traitor, and I can not

Owe thanks to traitors nor endure them round me,

However useful in this world they are.

For this I judge aright! If you had been

The man you seemed to be, God would have had

To work a miracle, He would have had

To give the very air the tongue it lacks;

That $\mathrm{He}$ foresaw when $\mathrm{He}$ created you,

So $\mathrm{He}$ made you the foremost of dissemblers!

Soemus. No! That I am not! I was Herod's friend,

I was his brother-in-arms and his companion

Before the throne was his, I was his servant,

Most faithful servant, after he was king.

But only while in me he recognized

The human being, honored him in me,

As I in him the hero and the king.

And that he did, until, unworthily

Dissembling, he cast down his eyes and gave

The dread command by which he heartlessly 
Consigned both you and me to certain death,

Exposed me to the vengeance of your people,

To Roman anger, and to his own spite,

As he did you to death at my sword's point.

I then had proof of what I meant to him!

Mariamne. And did you give expression to your horror?

2195

SOEMUS. I did not, for I wanted to protect you!

So I pretended to accept, dissembled,

If you prefer, so that he would not give

The order to another, and kill me;

A Galilean would have done the deed!

2200

MARIAMNe Forgive my words! You stand to him as I,

Like me you are offended in your inmost

Being, like me degraded to a thing!

$\mathrm{He}$ is a friend, just as he is a husband.

Come to my feast! (exit)

2205

ALWXANDRA. So you were waiting too, biding your time,

As I!

Sozmus. My time? What do you mean by that?

ALEXANDRA. I always noted with astonishment

The way you bowed before this king, who owed

His high position to the Roman's whim,

The reveller's drunken ecstacy and not

To race and birth, as if you had forgotten,

As he had, that you are his equal; now

I see your aim, you only planned to make

Him feel secure!

SoEmus.

In that, you are mistaken!

2215

I spoke the truth in all. I do not think

I am his equal and I never shall!

I know how many rogues there are who serve him

With grumbling only for the reason: Herod

Is not his grandson; I know others only

2210

Are loyal for the sake of Mariamne;

But I do not belong to any group

That rather would obey an infant's sword,

That is inherited, than hero's sword,

That is but freshly forged and fire hardened.

I always looked upon him as superior,

I was as ready to pick up his shield

For him, my friend-in-arms, when he might let

It fall, as ever the scepter for the king!

The crown, the best of women, never did I

Begrudge him either, for I felt his worth!

Alexandra. But you too are a man!

SozmuS.

That I have not

Forgotten that, is what I now am proving!

None is so great that he may use me as 
A tool! Whoever asks a service of me

Which-done or not done as it comes-consigns me

Disgracefully to certain death, that man

Frees me from every duty; him I have

To show, that there exists a middle step

Between the one for kings and that for slaves

2240

And that on this stands man!

Alexandra.

It makes no difference

Just what your reason: it's enough to find

You on my side!

SoEmus. No longer fear a struggle,

$\mathrm{He}$ is as good as dead! Octavius

Is not an Antony, who lets one hack

2245

Away his flesh and then forgives it freely,

Because he so admires the hand that does it!

He only sees the blows!

ALEXANDRA.

And Titus says ...?

Soemus. He thinks as I! I freed your Sameas

Only because I wanted her to call

2250

Me to account. That was the only way

I knew to get a hearing with the Queen!

She knows now what she has to know, and is

Prepared for it when news of death arrives.

That was my purpose! What a noble woman!

2255

Kill her! A pity, even if she wept!

Alexandra. Surely, a tender husband!-Talk to her,

Persuade her if you can that she should seek

Protection with the Romans, and yourself

Come to the feast by which she breaks with Herod,

Be he now dead or still alive! (exit)

SCEMUS (following her).

He's dead!

\section{SCENE 4}

Servants enter and make arrangements for the feast.

Nioses. Well Artaxerxes? Lost again in thought?

Come, come! You're not the clock with us, you know!

ARTAXerXes. If you had had that job for years, as I have,

Then your reactions would be quite like mine!

Especially if every night you dreamed

You had the former duty to discharge!

With my right hand I grasp the left hand's pulse

Involuntarily and count and count

And often count to sixty beats, before I

Remember I no longer am a clock!

Moses. Remember then that here with us your job

Is not to measure time! For that we have

The sundial and the sand! And you have things 
To do in time, just like the rest of us!

2275

It's loafing, nothing else!

ARTAXERXes.

I swear it's not!

MOSES. Be still! You never count while you are eating!

And furthermore, we do not swear here either,

And (to himself) if the King himself were not half Gentile

We would not have a foreign servant either!

2280

There the musicians come already! Hurry! (joins the others)

JEHU. You, is that really true what people tell

About you?

ArtaXerXes. Why then should it not be true?

Must I confirm the tale a hundred times?

That at the satrap's court I was the clock

2285

And was much better off than here with you!

At night I was relieved, then 'twas my brother,

And daytimes too, when it was time to eat.

I do not feel so grateful to your King

That with the other prisoners of war

2290

He dragged me here. I grant my work at last

Was getting hard. I had to go along

To war, and when you see the arrows flying

And people falling all around, you are

More apt to miss the count than in a hall

2295

Where people come together for a dance.

I shut my eyes, for I am not a hero

The way my father was. An arrow hit him

While at his post-he also was a clock,

As we, my brother too, and I, we all

2300

Were clocks-he called the hour and died! How's that?

That was a man! That took a deal more courage

Than it required to shoot the arrow at him!

JEHU. Have you no sand at home then? Is that why

You have to do that?

ARTAXERXES.

We? Have we no sand?

2305

More than enough to cover all Judea!

It's only that our satrap, so they say

Has every thing much better than the others.

The pulse of man, you know, beats more exactly,

If he is well and does not have a fever,

2310

Than ever any sand runs through a tube.

And of what use to you are sundials then,

On days it does not suit the sun to shine?

(counts) One- two-

Moses (returns). Be off! The guests are coming now!

ARTAXERXes. Is that a feast? I have seen different feasts,

Where only food was eaten that had come

From foreign countries! Where a guest was punished, Yes even put to death, if he should dare 
To drink a drop of water, and where men

Who had been wrapped in hemp well soaked with pitch

Were later set ablaze and burned by night

As torches in the gardensMoses.

Stop! What crime

Against your satrap had those men committed?

ARTAXERXes. Committed? Nothing! Funerals with us

Are much more splendid than are weddings here!

2325

Moses. Presumably you feast upon your dead?

That would go well with all the rest!

ARTAXERXES.

Perhaps

It is not true then either that your Queen

Dissolved a pearl once in a glass of wine,

A pearl more valuable than all the kingdom,

And that she gave a beggar this same wine,

Who drank it as he would have any other!

Moses. That is not true, thank God!

ARTaXroxes (to Jehu).

You said it was!

JEHU. Because it seemed to me to be an honor for her

And I had heard it told of the Egyptian!

Moses. Get out!

ARTAXMRXES (points to the roses Jehu carries).

Are those real roses? They are cheap,

With us all roses are of gold and silver!

They ought to send them where the flowers are

As valuable as gold and silver here!

The servants scatter. The guests, Soemus among them, have

been gathering during the last half of this scene. Music.

Dancing. Silo and Judas leave the others and step forward.

Sila. What is the reason for this feast?

JUDAS.

The reason?

The King is coming back! And that today!

Sino. Really?

JUDAS. How can you ask! What other reason

Could there well be for such a festival?

Best practice some new way to bow and scrape!

Silo. Did they not say-

JUDAS.

All lies! It always is

When rumor says some ill has come to him!

And that is natural, there are so many

Who wish him ill! Besides, do people dance

In homes where they are mourning for the dead?

Silo. Then very soon the blood will flow in streams,

The jails are full to bursting since the riot!

JUDAS. I know that better far than you can know it,

I dragged so many into jail myself.

This riot was so absolutely senseless

That everyone was forced to fight against it 
Who did not crave a hanging for himself.

You know I have no love at all for Herod,

However deeply I may bow before him,

But what he says is right: the Romans are

Too powerful for us, we are no more

2360

Than insects are within the lion's jaws,

They dare not sting, for they would be devoured!

SiLo. I'm only sorry for my gardener's son

Who threw a stone right at a Roman eagle

And hit it too! That is hard luck for him.

2365

JuDAs. How old is he?

SiLo. How long ago was it

I broke my ankle?-That's when he was born,

For then his mother could not be my nurse,

That's right-he's twenty!

JUDAS.

There's no danger then!

(Mariamne and Alexandra appear)

The Queen! (starts to go)

SiLo.

Why not? What do you mean? Explain!

JuDAs. Well then! In confidence! Since he is twenty

There is no danger, but were he nineteen

Or twenty-one, it would be bad for him!

Next year it will be different! SiLo.

Do not joke!

JUDAS. I tell you it is true! You wonder why?

The King himself is father of a son

Of twenty years, and yet he does not know him!

When he deserted her, the mother took

The child away and swore a solemn oath

She would corrupt the childSilo.

Frightful woman!

A Gentile?

JUDAS.

$$
\text { Probably! I do not krow!- }
$$

But so that he would have to kill his son,

You understand? I think it was a frenzy

Which then subsided after her first rage,

Yet he is anxious, and no decree of death

Has ever been enforced against a man

Whose age was that of Herod's son.

Comfort your gardener! But keep it to yourself!

(they lose themselves among the others)

\section{SCENE 5}

Alexandra and Mariamne in the foreground.

ALEXANDRA. You will not seek protection of the Romans?

MARIAMNE. Why should I?

ALEXANDRA.

To be sure you stay alive! 
Mariamne. Alive! Of course! One has to stay alive!

Pain has no sting unless one is alive!

ALEXANDra. At least then you should give the hour its due!

You hold a feast, so you should show your guests

A festive face, as is but fit and proper!

MARIAMNE. I am no instrument nor yet a candle,

Am not supposed to sound nor yet to shine,

So take me as I am! No! Do not do it!

Urge me to whet the axe for my own neck,

What am I saying, urge me to make merry-

2400

Cheer up, Soemus!

(to Salome as she enters and approaches)

You Salome? Welcome

Especially to me, although in mourning!

I scarcely hoped for that!

\section{SCENE 6}

SALOME. I have to come

If I desire to know how matters stand!

I am invited to attend a feast

But no one tells me why the feast is held!

I may suspect, but really I must know!

You are expecting Herod back? We shall

See him today? The candles tell me yes,

The merry music! You must tell me too!

I do not ask for me! But as you know-

No, no, you do not know, you have forgotten,

Perhaps you dreamed that she was dead and buried,

Else you would not have kept the news from her,

Only your dream deceived you, for she still

Is sitting in the corner where she sat

When she blessed you-

MARIAMNE.

What is it you are saying?

SALOME. Enough! For Herod has a mother still,

Who pines away with worry for her son.

And I, I beg you: Do not let her longer

Do penance for the crime of bearing me,

Give her the comfort which her heart requires!

MARIAMNe. I have no comfort I can give his mother!

Salome. Today then you are not expecting Herod?

MARIAMNE. No, not at all! I heard that he was dead!

Salome. And yet you celebrate?

MARIAMNE.

Since I still live!

And shall one not rejoice that one still lives?

Salome. That-I do not believe!

MARIAMNE.

Thanks for your doubt!

SALOME. The candles- 
MaRIAMNE.

SALOME. The cymbals-

MARIAMNE.

SALOME (point

The jewels-

MARIAMNe.

SALOME. That indicates-

MARIAMNE.

A joyous festival!

SALOME. But held above a grave-

MARIAMNE. Quite possible!

SALOME. Then-Mariamne, hear a serious word!

I always hated you, but always I

Have doubted whether it was justified,

And penitent I often came to you

To-

Mariamne. Kiss me! Once you even did it too!

SALOME. But now I see that you are-

MARIAMNE.

Rude enough

To leave you standing here alone, and join

2440

The group beginning dancing over there!

Soemus!

Soemus (offers his arm). Yes, my Queen!

MiARIAMNE.

I am quite sure

That Herod saw me thus, when he gave you

The bloody order. Is it not amazing!

Now everything has come as he expected!

You will look on?

(as she goes away, to Salome)

(with Soemus backstage where they are no longer seen)

SALOME.

This woman is still worse

Than I had thcught! And that is saying much!

That's why she has the brilliant serpent's skin

With which she lures all men!-Yes, she is dancing!

Well, truly, now my conscience is at rest,

No one on earth can do her an injustice!

(she watches Mariamne)

\section{SCENE 7}

Alexandra comes with Titus.

AleXandra. Titus, you notice how my daughter mourns! Titus. Perhaps she has some further news from Herod?

AlEXANDRA. The news that all is over with him! Yes!

Trus (looks at Mariamne).

She dances!

ALEXANDRA. Like a bride, not like a widow!

Titus, until today she wore a mask;

And, mark you, she was not the only one! 
Titus. It's for her good! She stays then what she is! If she is one of Herod's enemies

She will not have to suffer with his friends!

AlExandra. To show us that, she gives this festival!

(turns away from Titus)

Tirus. These women send a thrill of horror through me!

The one hews off the hero's head, whom she

Has just won over with her traitorous kisses,

While he is still asleep, the other dances

Like mad upon the grave of her dead husband

Because she wants to keep the crown herself!

I surely was invited here to see that-

(he looks at Mariamne again)

Yes, yes, I see and will report in Rome-

But here I shall not drink a drop of wine!

Salome. Well, Titus, what do you say? Is the King

So badly off that she may venture all?

Tirus. If he did not go over to Octavius

At once and help to give Mark Antony

The final blow even before his fall,

And that I doubt, then things look bad for him!

SALOME. If he had only done it!-If she should keep

Her head, then I do not know why the Lord

Gave dogs the flesh of haughty Jezebel

To eat! (she mingles with the others)

Trivs. She goes on dancing, but it seems

It is not easy for her! She ought to glow,

But she is pale, as if in thought she were

Some other place and only following

The dance mechanically! Well even Judith

May well have felt some fear while at her task!

This woman too must still feel on her lips

The last kiss of the husband whom she now

So solemnly renounces here before me,

And she has not yet seen him dead!-She comes!

Mariamne appears again. Alexandra and Soemus follow her.

AleXANDra (to Mariamne).

I spoke with Titus!

MARIAMNE (as she turns sees her image in the mirror)

$\mathrm{Ha}$ !

Alexandra. What is the matter?

MARIAMNE. Just so I saw myself once in my dreams!-

So it was that, which would not let me rest

Until I found the ruby I had lost

Which gleams so somber now upon my breast:

The picture would not be complete without it!-

The last scene follows soon!

ALEXANDRA.

Come to yourself! 
Mariamne. Let me alone!-A mirror quite like that!

At first a little dimmed as by the breath

Of someone, then quite gently clearing, like

The images it showed me one by one,

2500

And gleaming finally like polished steel.

I saw my life entire! First I appeared

A child enveloped in a rosy light

That slowly changed into a deeper red:

The features, though my own, seemed strange to me

2505

And only in the third clear transformation

I recognized my own too youthful face.

And now there came the maiden and the moment

When Herod led me to the flower garden

And said to me with ardent flattery:

of all these flowers none is too beautiful

For your dear hand to pluck!-Accurst be he

That he forgot it so completely!-Then it

Became uncanny and against my will

I had to see the future. So and so

2515

I saw myself-and last as I stand here!

(to Alexandra) Is it not strange, a dream so comes to life?-

The gleaming mirror now grew dull again,

The light turned ashen hue and I myself,

Who had just been so glowing, was as pale

As if my blood had long been flowing out

From all my veins beneath this festive garment;

My flesh did creep, I cried: Now I am coming

As skeleton and that I will not see!

I turned away-(she turns away from the mirror)

2510

VoICES IN THE BACKGROUND. The King! (general commotion)

ALEXANDra.

What? Who?

\section{SCENE 8}

Herod enters, in military dress. Joab. Retinue.

Mariamne. It's Death! Grim Death! Yes, Death is here among us!

And unannounced, just as he always comes!

SAlome. Yes, death for you! You feel it close upon you!

My brother!

(she is about to embrace Herod, he pushes her away)

HeRod. Mariamne! (he draws near)

MARIAMNe. Draw your sword!

Prepare the poison cup! For you are Death!

And Death's embrace and kiss is sword and poison!

HERod (turns to Salome). What does it mean? Already from afar

A thousand candles called out through the night:

Your messenger is safe, he was not captured 
By Arabs, he arrived, you are expected,

And now-

SALOME. The candles have deceived you badly,

They were rejoicing here, they thought you dead!

Your messenger did not arrive, your mother

Has rent her garments over you!

(Herod looks around, sees Titus, and beckons him)

Titus (steps forward). It's so!

Here no man was prepared, not even I,

2540

To think you would desert Mark Antony

Before the battle lost at Actium

And join your force to Caesar's, as good judgment

So clearly counseled! That this is what you did

Is proved to me by your return. Well then!

2545

I-wish you luck!

MARIAMNe (joins them). And I lament the fact

That opportunity was not presented

To slay Mark Antony with your own hand.

Thus you would best have shown to your new lord

That you no more had interest in the old one;

2550

You would have brought your friend's head with you for him,

He would have paid you for it with the crown!

Herod. Shame, Titus, shame! You too think that of me?

I marched right down into Arabia

As Antony had bidden me to do,

But there I found no enemy! So I

Set out for Actium and it was not

My fault that I arrived too late. If he

Had held, as I believed he would and could,

I would (to Mariamne) have sought the opportunity

To pay him for the crown by giving him

Octavius' head! (to Titus) But he did not! He was

Already dead when I appeared, a friend

Was now no longer necessary, and I

Sought out Octavius; but not as king-

I laid the crown aside-I did not go

As beggar either. I drew my sword and said:

I planned to use this sword against you, might

Perhaps have colored it with your own blood

Had things been different here. But that is over!

I lower it before you, lay it down!

Consider now how firm a friend I was,

Not whose; dead Antony has set me free!

Henceforth I can be your friend if you will!

Tirus. And he?

HIEROD. He said: where have you left your crown?

I want to add another jewel to it,

The province you have lacked! For you shall feel 
It only in my generosity

That I am victor, not Mark Antony.

He never would have taken it away

2580

From Cleopatra, I present it to you!

TIrus. That-I should never have believed. I praise

Your star alone!

HEROD.

Oh Titus, do not praise it!

For I was spared for onerous tasks! Soemus!

(Soemus stays where he is and does not answer)

Did you betray me? You are mute! I know

2585

Enough! Away with him!

Soemus (while being led away). I make no plea!

But you may well believe I thought you dead!

Now do what pleases you! (exit) HEROD.

And after death

It all ends, does it not? Yes! Yes! My Titus,

If you had known the man as I - You would not

Be standing here as calm and self-possessed

As I am, you would gnash your teeth and froth

With rage and cry in anger: (to Mariamne) Woman, what did

You do to make him go so far?-Salome,

You were right, I must wash and wash myself-

I must have blood! The Court shall sit at once!

(to Mariamne) Still silent? Taking refuge in defiance?

And I know why! You still remember what

You were to me! It would be easier

To tear my heart out of my breast-yes, Titus-

Than (again to Mariamne) you out of my heart. And yet I do it!

MARIamne (turns abruptly).

I am a prisoner?

HEROD.

Yes!

MARIAMNE (to the soldiers). Take me hence!

(turns-at a sign from Herod, Joab follows her with soldiers)

Death can not be my husbard any longer! (exit)

HeRoD. Ha! Ha! Once long ago I said to her:

Two people can not ever one outlive

The other, if their love is deep and true,

And even if I fell on distant fields;

One would not need to send a messenger,

For you at once would feel it when it happened,

Without a wound would die with me of mine!

Oh Titus, do not laugh at me! It's true!

But people do not love each other so! (exit) 


\begin{abstract}
ACT V
Large audience room as in the first act. Throne and judges' table.
\end{abstract}

\title{
SCENE 1
}

Herod and Salome.

HEROD. Enough! I have directed that the Court

Shall sit and I shall execute its sentence!

Yes I, who used to fear each sign of fever,

And if it only struck her waiting-woman,

Now I myself am arming death against her!

It is enough! And if your zeal will still

Not let you rest, then it will miss its goal

And I shall surely think that hate alone

Speaks from your lips, and as a witness shall

Reject you, even though I let each candle

Bring evidence, that was ablaze that night,

And every flower that filled the air with fragrance!

SAlome. But Herod! I will not deny that I

Have often hunted for her failings and

Have magnified them, just as you the virtues

That you discovered in her. Could the pride

With which she never failed to treat your mother

And me, could such a pride inspire love?

She thought herself a higher type of being,

But one which never did arouse in me

Another thought than this: What is the need

Of that thick book in which we are informed

About the Maccabees' heroic deeds?

The chronicle is written on her face!

HeRod. Your aim is to refute me, and you seal

The judgment I pronounced!

SALOME.

Pray hear me out!

I grant that it was so. But if I now

Said more than what I know and think and feel,

Yes, if because of sisterly compassion

I did not still lock in my breast the half

Of what I might have said, then may my child-

I love him dearly!-live as many years

As there are hairs that grow upon his head,

And may each day bring him as many pangs

As it has minutes, yes, as it has seconds!

Herod. The oath is terrible!

SALOME.

And yet I find

It easier to say than: Night is black!

My eye might well be sick, but scarcely could

It be, that at the same time with the eye 
The ear be sick, the heart, the instinct, all The other organs that support my senses! And this time all of them are in agreement, As if they could not contradict each other. 2655 Yes, if upon that festive night the Lord Had cried out to me from the vault of Heaven:

From what dire evil shall I free your earth, You have your choice, then I would not have named The plague, I would have named your wicked wife! I shuddered at the sight of her, it seemed As if I had stretched out my human hand In darkness to a demon out of Hell And he were scoffing at me for it, stepping Forth from that stolen body of flesh and blood And in his own so terrifying form Were leering at me through the smoke and flames;

Not only I was shuddering so, even

The Roman, hardened Titus, was amazed!

HEROD. Indeed, and he weighs heavier than you,

For as he loves no one, he hates no one, And he is just, like spirits without blood. Now leave me, for I am expecting him!

SALOME. No, no, I never shall forget this dance At which she moved in rhythm with the music 2660 And yet as if she knew for certain you Lay dead beneath the ground! By God, I would I did not have to say that! For I know How it must rouse you, who have sacrificed Your mother, sister, and much more for her! But so it was! (exit)

\section{SCENE 2}

HEROD (alone). What Titus told me was

The same! Besides I saw enough myself!

And she is right! I sacrificed my sister For her, almost my mother: would not they Outweigh the one, the brother she has lost? In her eyes they would not!

\section{SCENE 3}

Titus enters.

HEROD.

Well, Titus, has

Soemus yet confessed? Titus.

The things you know!

No more!

HEROD.

And not- 
Titus.

Oh no! He flared right up

In rage when I remotely hinted at it!

HEROD. I could expect it!

TITUS. Never had there lived

A wife like yours and never had there been

A man so little worthy of the jewel

That God had granted him-

HEROD.

As I myself!

Yes, yes!- "He did not know what pearls were worth,

Therefore I stole them from him," said the thief.

2695

I do not think it helped.

Tirus.

Her heart was rarer

Than gold-

HeRoD. He knows it? $\mathrm{He}$ is all aglow,

Praises the wine! Is that not proof enough

That he has tasted it? What reason did

He give you? Why did he betray my order

2700

To her?

Tirus. Abhorrence, so he said!

HEROD. Abhorrence?

And did not say a word to me about it?

Titus. Would that have been advisable for him?

Could you have let the stubborn servant live

Who ever once received an order from you

2705

And then refused it?

HEROD.

Was it not enough?

In such a case, to leave it unfulfilled?

Trus. Of course! If he went further, then he did it

Perhaps because you seemed already lost

And now at your expense he may have wished

2710

To gain himself the favor of the Queen

In whose two hands his future fortune lay.

FiERoD. No, Titus, no! Soemus was the man

To risk the stroke himself, that makes the favor

Of any other quite unnecessary!

2715

Therefore I gave the charge to him, I thought:

He certainly will do it for himself,

If not for you! Were he a lesser man,

Did he not have so many friends in Rome,

I might perhaps believe, but now-No, no!

2720 Titus.

There was one reason only!

Admit that one!

HEROD.

Yet he will not

$\mathrm{He}$ is, if he admitted it. He knows

Full well what must now follow and he hopes

By his denial to awake in me

A final doubt which, if it does not save 
His head for him, may yet guard hers from death!

But he is wrong, the doubt lacks any sting,

For had I nothing that she did to punish,

I have what she became and what she is!

2730

Ah! Had she ever been what she appeared:

She never could have so transformed herself;

And I take vengeance on the hypocrite!

Yes, Titus, yes, I swear it by the key

To paradise she holds within her hands;

2735

By all the happiness which she has brought

To me, and all the joy she still could bring;

Yes by the shudder which just now has warned me

That I shall but destroy myself in her:

Yes make an end, however it may be!

Tirus. It is too late to cry a warning to you:

Oh do not give the order! and I know

No means myself that can bring clarity

And so I do not dare to say: Desist!

\section{SCENE 4}

\section{Joab enters.}

HEROD. Are they convened?

JOAB.

Long since! And from the prison

I must report what seems important to me!

I must report that Sameas can not

Be brought to kill himself!

HERoD.

My order was

That torture be inflicted till he does!

(to Titus) I heard that he had sworn to kill himself

If he could not make me the like of him,

Not break the Gentile streak in me-

He calls it that. Since he did not succeed

In that, I force him now to keep his oath,

He has deserved that death a thousandfold!

TITUs. I would have strongly urged his death myself,

He has affronted me and Rome in me

And that can everywhere be freely pardoned

But not here, where the people are so headstrong!

Herod (to Joab). Well then!

JOAB.

They did exactly as you ordered,

Only it did not help at all. The hangman

Tried almost every torture on him. He gave

Him wounds besides, for he was angered so

By his defiance, which he took for scorn,

But it is just as if he lashed a tree,

As if he had been cutting into wood:

The old man stands as if he had felt nothing, 
He sings instead of screaming and makes no move

To grasp the dagger which they hold before him,

He sings the psalm the three men sang when they

Were in the burning fiery furnace, sings

More loudly still at each new pang of torture,

And when he stops, he even prophesies!

Herod (aside). Yes, that is how they are!-Will she be different?

JOAB. As if he had received the gift of eyes

For secret and mysterious things, as many

As he has wounds, he cries aloud: The time

Is now fulfilled and at this sacred moment

The Virgin Mother of the tribe of David

Is laying in the manger bed a Child

2780

Who will cause thrones to topple, wake the dead,

Tear stars from Heaven, and will rule the world

From everlasting, unto everlasting!

The mob meanwhile has gathered there in thousands,

Awaits outside the gates, hears everything,

Believes Elijah will again send down

The chariots of fire to carry him

To Heaven like the prophet. Even a hangman

Was terrified and held the old wounds closed

Instead of wounding him anew!

Put him to death at once; when he is dead,

Shall show him to the people!-And then bid

The judges come as well andJOAB. and the Queen! (exit)

HEROD. You, Titus, will please sit beside me here!

I also sent a summons to her mother,

So she shall feel no lack of witnesses.

\section{SCENE 5}

Aaron and the other five judges enter. Alexandra and Salome follow. Joab enters immediately after them.

ALEXANDRA. My King and Lord, I give you greeting! HEROD.

Thank you!

He seats himself upon the throne, Titus sits down beside him, the judges at a sign from him take seats in a semicircle round the table.

ALEXANDRA (while this is taking place).

I think of Mariamne's fate as something

Distinct from mine, and save myself, as if

I were a torch, for what is yet to come.

HEROD (to the judges).

$$
\text { (she sits down beside Salome) }
$$

You know why I have had you summoned here!

AARON. It was with deepest pain that we appeared! 
HEROD. I do not doubt that! You are all related

Or stand on terms of friendship with my house,

So what hurts me, hurts you! You will be glad

Then, if the Queen, whom I-(he hesitates) But spare me that!

You will be glad, if you do not condemn her,

If you may send her home to me, instead

Of sending her to Golgotha, and yet

If that necessity arises, you will

Not lose your courage but will face the worst,

For as you share my fortune and misfortune

So you will share disgrace and honor too.

Proceed then!

He gives Joab a sign. Joab goes and returns with Mariamne.

HEROD.

A long pause follows.

An easy one! You stand before your judges!

MARIAMNE. Before my judges, yes, and also you!

Aaron. Do you not recognize this Court?

MARIAMNE.

I see

A higher one! If that permits an answer

To questions that you ask, then I shall speak, And shall keep silent, if that Court forbids!-

2820

$\mathrm{My}$ eyes can scarcely see you, for behind you

Stand spirits that regard me, silent, solemn;

They are the famous forebears of my race.

For three long nights I saw them in my dreams

And now they come by day as well, I know

2825

Exactly what it means to see the dance

Of death already opened up for me

And all who live and breathe becoming pale;

There right behind that throne on which a king

Appears to sit, stands Judas Maccabaeus:

2830

Hero of Heroes, gaze not down so darkly

On me, you shall be satisfied with me!

Alexandra. Not too defiant, Mariamne!

MARIAMNE.

Mother!

Farewell!-(to Aaron) of what then do I stand accused?

AlRoN. That you deceived your king and husband-

That right?

(to Herod) Is

MARIAMNE. Deceived? And how? Impossible!

Did he not find me as he thought he would?

Did he not find me dancing and at play?

Did I put on deep mourning when I heard

That he was dead? Did I shed tears of grief?

Or tear my hair? Oh, I would then have been

Deceiving him, but I did not do that 
And I can prove it. Speak your mind, Salome!

HERoD. I found her as she says. She does not need

To look around to find another witness.

But never, never had I thought it of her!

MARIAMNE. Not thought it? Yet you stationed close behind me

The hangman in his mask? That can not be!

For as I stood before his mind at parting,

Just so he found me after his return,

And so I must deny that I deceived him!

HEROD (breaking out in wild laughter).

So she did not deceive me, since she only

Did what foreboding, premonition let

Me fear-How much I praise that sinister

Admonisher!-(to Mariamne) Ah! Woman! That is like you! 2855

But do not build too much upon the hope

That I, with joy and peace, have also lost

My strength, perhaps enough is left for vengeance

And-even as a boy I always shot

An arrow after birds if they escaped me.

2860

MARIAMNE. Speak not of premonition and foreboding

But speak of fear alone! You quaked at that

Which you deserved! That is the way of man!

You can no longer trust the sister, since you

Have put to death the brother; you have done

Most frightful things to me and now you think

I must reply, yes, even must outdo you!

No? Or did you, when you were facing death

In honest open warfare, always station

A hangman right behind me? You are silent?

It's well. Since you yourself do feel so deeply

What is most fitting for me, since your fear

Instructs me what my duty is, so then

I finally fulfill this sacred duty,

And separate myself from you forever!

Herod. Answer! Do you confess? Or do you not?

MARIAMNE (is silent).

HEROD (to the judges).

You see, there is no frank confession! Also

I do not have the proof you like to have!

But once you did condemn a murderer

To death because one of his victim's jewels

2880

Was found on him. It was of no avail

To show his hands, which he had washed so clean,

Nor yet to swear the dead man's jewel had been

A gift; you had the sentence carried out!

It stands the same way here! She has a jewel,

An evidence, more incontestible

For me than any human tongue could give, 
That she is guilty of the sin of sins.

A miracle would not have merely happened, It would have had to be repeated, were it

Not so, and miracles are not repeated!

MARIAMNE (moves as if to speak).

HEROD. Yes, she will say, just as the murderer said:

It had been given her! And she may risk it,

For like a forest, bedrooms too are mute.

But if you should be tempted to believe her

2895

Then all my inmost feelings contradict you

And every explanation possible is

Against you too, and I demand her death.

In truth, her death! I do not want to drain

The loathesome cup defiance offers me,

2900

Nor to torment myself from day to day

With wondering whether such defiance is

The most unpleasant face of innocence, or

The boldest mask of sin, I want to save

Myself from this mad whirl of love and hate

2905

Before it stifles me, cost what it may!

And so away with her!-You hesitate?

That is my will!-Or do you differ with me?

Then speak! I know it's time that I were silent!

So speak then! Do not sit like Solomon

2910

Between the mothers with the two young babes!

The case is clear! To judge, you need no more

Than what you see! A woman, who can stand there

As she does, merits death and were she free

From every guilt! And still you do not speak?

Do you perhaps first want the proof, how firmly

I am persuaded that she has deceived me?

I give it to you with Soemus' head,

And that at once! (he turns to Joab)

Titus (rises). I don't call this a court!

Pardon! (he is about to go)

MARIAMNE. No, Roman, stay, I recognize it!

And who will challenge it, if I do not!

(Titus sits down again, Alexandra stands up, Mariamne steps

up to her, in an undertone)

You have brought sorrow to me, never have

You judged your happiness in terms of mine!

If I'm to pardon that, keep silence now!

You will not alter what I have resolved!

Well, judges?

$$
\text { (Alexandra sits down) }
$$

AARON (to the rest). Any one of you who thinks

The King's decree unjust, let him arise!

(all remain sitting) 
So you have all decreed that she shall die!

$$
\text { (he stands up) }
$$

You are condemned to death, my Queen!-Have you

Aught else you wish to say?

Has had his orders in advance, already

Is waiting for me with the axe, I wish

To speak with Titus yet, before I die.

(to Herod) It is the custom to allow a wish

To one about to die. If you can grant it,

Then let my life be added to your own!

Fierod. The hangman has no orders yet-I can!

And since you promise me eternity

As my reward for that, I must and will!

(to Titus) Is not this woman terrible? Titus.

She stands

Before a man, as woman never should!

So make an end of it!

SALOME (steps forward). Oh do! Your mother

Is sick and close to death! She will recover

When she has heard this!

HEROD (to Alexandra). Did you not say something?

ALEXANDRA. No!

HeRod. Die! (to Joab) I put it in your hands! (exit rapidly, Salome follows)

ALEXANDRA (looking after him). For you

I have another barb! (to Mariamne) That was your wish!

MARIAMNE. I thank you! (exit Alexandra)

AARoN (to the other judges). Shall we still not try to bring

Him to relent? For this is horrible!

She is the last of all the Maccabees!

If we could but obtain a brief delay!

2950

It would not do directly to oppose him

But he himself may soon again be different,

And it may be that he will punish us

Because today we offered no resistance!

So come! (exeunt)

JOAB (to Mariamne). Will you forgive? I must obey!

MARIAMNE. Do what your master ordered, do it quickly!

I shall be ready just as soon as you

Yourself, and queens, as you know, do not wait! (exit Joab)

\section{SCENE 6}

MARTAMNe (steps up to Titus).

Just one word more before I go to sleep,

While my last chamberlain prepares the bed! 
You are astonished, as I see, that I

Direct this word to you and not my mother,

But she is almost like a stranger to me.

Tirus. I am amazed to have a woman show me

How as a man I have someday to die!

2965

Yes, Queen, your actions seem to me uncanny,

And, I will not deny, your nature too,

Only I must acmire the heroic spirit

Which lets you leave this life as if the world

With all its beauty seemed not even worth

2970

Another hasty glance on your last walk;

This courage almost reconciles me with you!

Mariamne. It is not courage!

TITUS.

To be sure, they say

It is a teaching of your gloomy Pharisees

That life does not begin till after death,

And all those who believe with them despise

The world in which the sun alone shines on

And everything besides dies out in night!

MARIAMNE. I never listened to them, I do not

Believe it! No, I know what I am leaving!

Trus. Then you stand there, as scarcely Caesar did

When Brutus' hand had thrust the dagger home,

For he, too proud to let his pain be seen,

And yet not strong enough to stifle it,

In falling covered up his face; but you

Are keeping it concealed within your breast!

MARIAMNE. No more! No more! It is not as you think!

No longer do I suffer pain, for life

Is part of pain and life within me has

Become extinct, I long have been halfway

Between a person and a shadow, and

I scarcely understand just how I still

Can die. Now hear the things I have to say,

But first you promise me as man and Roman

That you will keep it silent till I'm gone,

That you will stay beside me when I go.

You hesitate? Do I demand too much?

It's not because I fear to stumble, and whether

You later speak or whether you keep silent,

Decide yourself! In nothing do I bind you,

I even let my wish go unexpressed.

This is the reason I have chosen you:

Because you always in the past have watched

Our Hell aloof and cold, just as a statue

Of bronze might look upon a burning city.

When you give evidence, they must believe;

We are for you a different race, to which 
No bond attaches you, you speak of us

As we do of exotic plants and stones,

Impartially and without love or hate!

3010

Titus. You go too far!

MARIAMNE.

If you unyielding now

Refuse your word, my secret goes with me

Into the grave, and then I must forego

The consolation that one human breast

Preserves my image pure and undefiled

3015

And that, if hatred dares its worst, he then

From sense of duty and respect for truth

Can lift the veil that hides it from the others!

Tirus. I yield! I promise it to you!

MARIAMNE.

So know then

That I deceived the King, but not as he

3020

Believes! I was as loyal to him as he

Himself. But why revile myself? More loyal,

$\mathrm{He}$ is long since another than he was:

Do I need to affirm that? I should rather

Decide to swear that I had hands and feet.

3025

For I could lose both hands and feet and yet

I should still be just what I am, but I

Could not lose heart and soul!

Trus.

Yes I believe you

And I will-

MARIAMNE. Keep what you have promised me!

I have no doubt! Now ask yourself just what

3030

I felt, when he placed me a second time

Beneath the sword: I had forgiven him once,

When I was forced to think: Your shadow is

More like you, than the so distorted picture

Of you he carries in his deepest soul!

3035

That was too much, I could not stand it longer!

I reached down for my dagger and, restrained

From sudden suicide, I swore to him:

You plan to be my hangman if you die,

You shall become my hangman, but in life!

3040

You shall now put to death the wife you saw

And after death shall see me as I am!-

You saw me at the feast. Well then: a mask

Was dancing there!

Titus.

Ah!

Mariamne.

And today a mask stood

Before the Court, and for a mask the axe

Is being ground, but falling it strikes me!

Tirus. You move me deeply, Queen, and I accuse you

Of nothing wrong, but I must say to you:

I was myself deceived, for at your feast 
You filled me with a horror and aversion

As now with shuddering thrills of admiration.

If that was the effect on me, why should not

The glamor of your mask have blinded him

Whose heart, so stirred by ardent feeling, was

As little able as a turbid stream

3055

To mirror things exactly as they are.

I feel deep sympathy for him as well

And so I find your vengeance too severe!

MARIAMNE. I take my vengeance at my own expense;

If dying like a sacrificial beast

Incensed me so, I now show it was not

Because of life; I throw my life away!

Titus. Release me from my promise!

Mariamne. If you broke it,

You would not change a thing. A man

Can have another put to death; the strongest

3065

Can not compel the weakest to live on.

And I am tired, I even envy stones,

And if it is the purpose of this life,

That one shall learn to hate it, to prefer

Eternal death to life, that purpose was

3070

Attained in me. Oh would that they might carve

My coffin out of never-crumbling granite

And sink it deep beneath the sea, so that

Throughout eternity my very dust

Be kept apart from all the elements!

Tirus. But we are living in a world of pretence!

MARIAMNE. I see that now, so I am leaving it!

TIrus. And I myself gave evidence against you!

MARIAMNE. I asked you to the feast, so that you would!

TrTus. And if I told him now, what you have told me-

MARIAMNe. He then would call me back, I have no doubt!

If I turned back, then my reward would be

That from that moment I should have to stand

In fear of any who approached, and say:

Take care, for that can be your third dread hangman!

No, Titus, no, it was not mere dissembling,

For me there's no return. And if there were,

Do you not think I would have found it out

When I took leave forever from my children?

If mere defiance drove me, as he thinks,

My children's sorrow would have broken it:

Now sorrow only makes my death more bitter!

Tirus. Oh, if he felt that, came himseif and fell

Down at your feet!

Mariamne.

Yes! That would show that he

Had overcome the demon and I could 
Tell everything to him! For I ought not

To stoop to bargain with him for a life

Which, by the very price at which it can

Be bought, must lose for me its every value;

I should reward him for his victory, and

Believe me, I could do it! Tirus.

Not feel it?

Herod, do you

Joab comes in noiselessly and stands there silent.

Mariamne. No! You see, he sends me him! (points to Joab)

TrTus. Let me-

MIARIamne. Did you not understand me, Titus?

In your eyes is it mere defiance still

That seals my lips? Can I continue living?

3105

Can I continue living with a man

Who does not honor God's own image in me?

And if the very fact that I kept silent

Could conjure death, provide the weapon for him,

Should I now break my silence? Should I merely

Exchange one type of dagger for another?

And would it have been more?

Titus.

She is quite right!

Mariamne (to Joab). Well, are you ready? (Joab bows)

MARIAMNe (toward Herod's chambers). Herod, farewell to you!

(toward the earth) To you, Aristobulus, my fond greetings!

Soon I shall join you in eternal night!

She goes to the door. Joab opens it. Armed men visible standing at attention. She goes out. Titus follows.

Joab last. Solemn pause.

\section{SCENE 7}

Salome enters.

SALOME. She went! And still my heart does not beat faster!

Another sign that she deserved her fate.

So finally again $I$ have my brother,

My mother has her son! It's well I did

Not budge from him. For otherwise the judges

Might still have changed his mind. No, Aaron, no!

Imprisonment! She would not stay in prison

A month. The grave alone will hold her fast,

For only for the grave has he no key.

\section{SCENE 8}

A Skrvant. Three kings have come here from the Orient

And bring with them rich loads of precious gifts,

They have arrived this very moment, never

Before have eyes beheld more foreign shapes 
Nor more amazing costumes here than these!

ShLOME. Have them come in! (exit servant)

I will at once announce them.

While they are here with him he will not think

Of her! And soon all will be over with her!

(she goes in to Herod)

The servant brings in the three kings, strangely clothed but different from one another. They are accompanied by a rich retinue similarly clothed. Gold, frankincense and myrrh. Herod enters with Salome immediately after.

FIRST KING. Hail King to you!

SECOND KING. And blessed is your house!

THIRD KING. Glorified in all eternity!

HEROD. Thank you! But for this hour your greeting seems

3135

Quite strange to me!

F'IRST KING.

Was not a son just born

To you?

HEROD. To me? Oh no! My wife has died!

FIRST KING. Then this is not the place for us!

SECOND KING.

There is

A second king besides you here!

HEROD.

There would

Be none here then.

3140

THIRD King. Besides your own there is

A second royal family in the land!

HEROD. But why?

FIRST KING.

Then it is so!

SECOND KING.

It must be so!

HEROD. I do not know of one!

SAlOME (to Herod). In Bethlehem,

They say, a branch of David's race has been

Preserved!

ThIRd KING. And David was a king?

HEROD.

He was!

FIrST King. Then let us go on down to Bethlehem!

SALOME (continuing to Herod).

But his descendants there are only beggars!

H.EROD. That I believe! Else-

SALOME.

Once I saw a maid

Of David's house and spoke with her, her name

Was Mary. She was beautiful enough

And was betrothed, but to a carpenter,

She scarcely lifted up her eyes toward me

When I was asking for her name!

HEROD.

You hear?

SECOND KING. It matters not, we go!

HEROD.

But will you tell,

Before you go, what brings you here? 
FiRST KING.

For Him the King of Kings!

SECOND KING. And the desire

To see Him face to face before we die!

ThIRD KING. The sacred duty to do homage to Him

By laying at His feet the precious things

Of earth!

HEROD.

But who told you of Him?

First King.

His star!

We did not start together, had no knowledge

Of one another, and our realms lie far

Apart in East and West, and there are seas

Between them and high mountains cut them off-

SECOND KING. But all of us had seen the selfsame star,

3165

The same desire had seized all three of us.

We traveled by the selfsame route and here

We came together at the selfsame goal-

THIRD KING. And whether $\mathrm{He}$ be son of king or beggar,

The Child for whom this star shines out on life,

Will be exalted high, and on the earth

No man will breathe who does not bow to Him!

HEROD (to himself).

The ancient book predicts that too! (aloud) May I

Supply a guide for you to Bethlehem?

FIRST KING (pointing to the sky).

We have one!

3175

HEROD.

Good-when you have found the child,

Will you be sure to send me word of it

So that I can, like you, pay homage to it?

FIRST KING. We will! And now away to Bethlehem!

(exeunt kings and retinue)

HEROD. They will not do it!

HEROD.

(enter Joab and Titus followed by Alexandra)

JOAB.

Ah!

It has been done!

(Herod covers his face.)

Tirus. She died. That's true. But I now have a task,

A task more terrible by far than he

Performed who carried out your bloody sentence:

I have to tell you, she was innocent.

HEROD. No, Titus, no!

(Titus starts to speak. Herod steps up to him.)

If that were so, then you

Would not have let her die.

Trus.

That no one could

Have hindered but yourself!-It gives me pain

That I must be for you far worse than hangman.

If it's a sacred duty to inter 
The dead, whoever he may be, then surely

To clear him from disgrace, if he does not

Deserve it, is a duty still more sacred,

And now this duty falls on me alone!

Fikrod. In all you say I only see one thing:

Even in death her charm was true to her!

Why still feel rancor toward Soemus! How

3195

Could he resist her-glamor while she lived!

About to die, she still enflamed your heart!

Tirus. Does jealousy extend beyond the grave?

HEROD. If I were wrong and if behind your words

Lay something other than a sympathy

That is too deep to be no more than that:

I should remind you still, your evidence

Had its full share in helping to condemn her,

And so you would have been in duty bound

To warn me, when you felt the slightest doubt!

Trus. My word prevented me and more than that!

A harsh, inexorable necessity.

If I had moved a single step from her

She would have taken her own life at once,

I saw the dagger hid upon her breast,

I saw her hand start toward it more than once.

(pause) She planned to die, she had to die, for she

Had suffered just as much, forgiven just

As much as she could suffer or forgive.

I saw deep down into her inmost soul.

Who asks for more should not find fault with her,

His quarrel's only with the elements

Which were so mixed in her that she could go

No further. But let him show me the woman

Who ever went as far as she had gone!

(Herod moves restlessly)

She wanted death from you and at her feast

She called into deceptive life that ugly

And fatal phantom of your jealousy

And thus deceived us all with an illusion.

I found it harsh but not unjust. She showed

Herself to you as mask, a mask intended

To prod you, make you draw your sword against her,

(he points to Joab)

You did and you yourself put her to death!

HEROD. She said that. But she spoke that way from vengeance!

TITos. She said it. I gave evidence against her,

How I should like to doubt it!

Trus. I met him on his way to death, he was

About to start on his when she had finished 
Hers, and it seemed to be a comfort to him

That his blood would be mixed so soon with hers

3235

If only on the block by hangman's hand.

HEROD. Ah! You see!

Tirus. What? It may be that he glowed

For her in secret. But if that was sin,

Then it was his, not hers. He called to me:

I die, because I spoke, but otherwise

3240

I should have had to die because I could

Speak. That was Joseph's lot! He swore to me

In dying, that he was as innocent as I! -

I noted that!

Herod (breaking out). Is Joseph too avenged?

The earth is opening up? Do all the dead

Step forth?

ALEXANDRA (steps up to him).

They do!-No! Do not fear! There was

A queen. She will remain below, I'm sure!

HEROD. Accurst-

(controls himself) So be it! Even if Soemus

Committed only one offense against me-

(turning to Salome)

Joseph, who filled him with this base suspicion,

3250

Joseph though facing death was lying to him,

Or no? Joseph-Why are you silent now?

SALOME. He dogged her every step-

ALEXANDRA (to Herod). I know, but yet

He only sought the opportunity,

And that is sure, to carry out your order

3245

To kill both her and me-

HEROD.

Is that the truth?

(to Salome) And you? you?-

ALEXANDRA. Almost in the very hour.

When he completely dropped the mask he wore

Then Mariamne made a solemn oath

To kill herself with her own hand if you

3260

Did not return. I will not hide it from you,

I hated her for that!

HEROD.

Oh! Terrible!

And that-you tell me only now?

ALEXANDRA.

I do!

TruUs. I know that too, it was her parting word,

A thousand years I would have kept it silent,

3255

I wanted to clear her, not torture you!

HIEROD. Oh then-(his voice fails him)

TIrus. Control yourself, it hits me too!

HsRod. Yes you-and her (toward Salome)-and everyone who was,

As I, the blind tool of malicious faie, 
But I alone have lost what on the earth

Will not be seen in all eternity

Again! Lost? Oh!

ALEXANDRA. Aristobulus! Now

You are avenged, my son, and $I$ in you!

HEROD. You triumph? Do you believe that I shall now

Collapse? Oh no, I shall not go to pieces!

3275

I am a king and will see to it that

(he makes a motion as if he were breaking something)

The world feels it!-Up then Pharisees,

Rebel against me now! (to Salome) You, why are you

Retreating from me now? As yet I have

No different face, but it can happen by tomorrow

3280

That even my own mother has to swear

That I am not her son!

$$
\begin{aligned}
& \text { (after a pause-with hollow voice) } \\
& \text { And if my crown }
\end{aligned}
$$

Were set with all the stars that flame on high,

For Mariamne I would give them all,

And if I had it, give the world besides.

Yes, I would even lay myself alive

Within the grave, just as I am, if I,

By doing that, could set her free from hers,

Yes, I would dig the grave with my cwn hands!

I can not do that! Therefore I hold fast

To what I have and keep on holding fast!

It is not much but with it is a crown

Which now must take the place of wife and queen.

And if one grasps for that - - But someone does,

A boy is doing it, the wonder child

Of whom the prophets long since spoke to us

And for whom now a star shines out on life.

But, Fate, your error was a grievous one

If you had thought to smooth the way for him

By trampling me beneath your brazen feet,

I am a soldier, I will fight against you

And still will bruise your heel though lying prone!

(quickly) Joab! (Joab stcps forward)

You go today to Bethlehem

And tell the captain who is in command there

To take the wonder boy-But he will not

Know where to seek, not all can see the star,

These kings are quite as false as they are pious-

Tell him to kill the children on the spot,

All children who were born in this last year, 
Not one of them must stay alive!

It's well!

JOAB (steps back).

(to himself) And I know why! But Moses still was saved In spite of Pharaoh!

HEROD (still loud and strong). I shall check tomorrow!

Today there's Mariamne-(he collapses) Titus!

(Titus catches him)

FINIS 



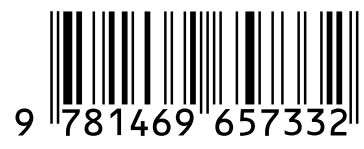

